\title{
Thoughts Regarding the Dimensions of Faults at Rainier and Aqueduct Mesas, Nye County, Nevada, Based on Surface and Underground Mapping
}

February 2011

Prepared for:

U.S. Department of Energy

National Nuclear Security Administration

Nevada Site Office

Las Vegas, Nevada

Prepared by:

Sigmund L. Drellack, Lance B. Prothro, and Margaret Townsend

Underground Test Area and Boreholes Programs and Operations

Environmental Restoration

National Security Technologies, LLC

Las Vegas, Nevada

and

Dean R. Townsend

Wastren Advantage, Incorporated 


\section{DISCLAIMER STATEMENT}

Reference herein to any specific commercial product, process, or service by trade name, trademark, manufacturer, or otherwise, does not necessarily constitute or imply its endorsement, recommendation, or favoring by the U.S. Government or any agency thereof or its contractors or subcontractors.

\section{AVAILABILITY STATEMENT}

Available electronically or paper from:

U.S. Department of Commerce

National Technical Information Service

5301 Shawnee Road

Alexandria, VA 22312

Telephone: 800.553 .6847

Fax: 703.605.6900

E-mail: orders@ntis.gov

Online ordering: http://www.ntis.gov/help/ordermethods.aspx

Available electronically at http://www.osti.gov/bridge.

Available for a processing fee to U.S. Department of Energy and its contractors, in paper, from-

\section{U.S. Department of Energy}

Office of Scientific and Technical Information

P.O. Box 62

Oak Ridge, TN 37831-0062

Telephone: 865.576.8401

Fax: 865.576.5728

E-mail: reports@adonis.osti.gov 


\title{
Thoughts Regarding the Dimensions of Faults at Rainier and Aqueduct Mesas, Nye County, Nevada, Based on Surface and Underground Mapping
}

\author{
Prepared for: \\ U.S. Department of Energy \\ National Nuclear Security Administration \\ Nevada Site Office \\ Las Vegas, Nevada
}

Prepared by:

Sigmund L. Drellack, Lance B. Prothro, and Margaret Townsend

Underground Test Area and Boreholes Programs and Operations

Environmental Restoration

National Security Technologies, LLC

Las Vegas, Nevada

and

Dean R. Townsend

Wastren Advantage, Incorporated

February 2011 
This page intentionally left blank. 


\section{Abstract}

The geologic setting and history, along with observations through 50 years of detailed geologic field work, show that large-displacement (i.e., greater than 30 meters of displacement) syn- to post-volcanic faults are rare in the Rainier Mesa area. Faults observed in tunnels and drill holes are mostly tight, with small displacements (most less than 1.5 meters) and small associated damage zones. Faults are much more abundant in the zeolitized tuffs than in the overlying vitric tuffs, and there is little evidence that faults extend downward from the tuff section through the argillic paleocolluvium into pre-Tertiary rocks. The differences in geomechanical characteristics of the various tuff lithologies at Rainier Mesa suggest that most faults on Rainer Mesa are limited to the zeolitic units sandwiched between the overlying vitric bedded tuffs and the underlying pre-Tertiary units (lower carbonate aquifer-3, lower clastic confining unit-1, and Mesozoic granite confining unit). 
This page intentionally left blank. 


\section{Table of Contents}

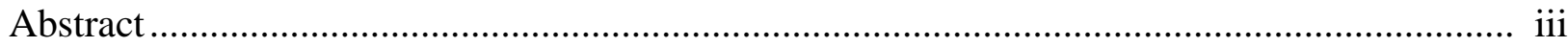

List of Figures ............................................................................................................... vi

List of Tables ............................................................................................................

List of Acronyms and Abbreviations .......................................................................................viii

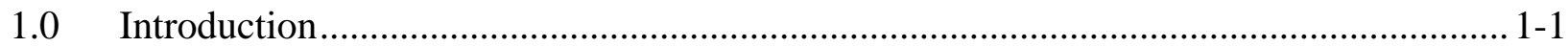

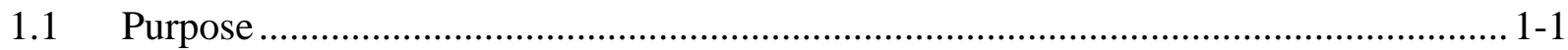

1.2 Hypothesis for Fault Extents in Rainier Mesa ............................................................. 1-1

1.3 Background Information ................................................................................ 1-1

2.0 Geologic and Structural Setting .......................................................................... 2-1

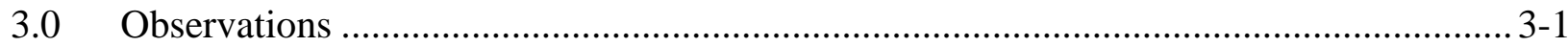

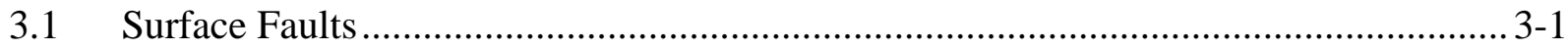

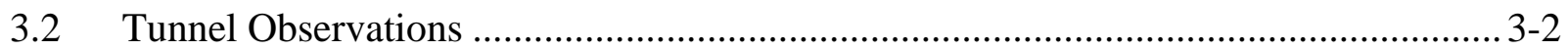

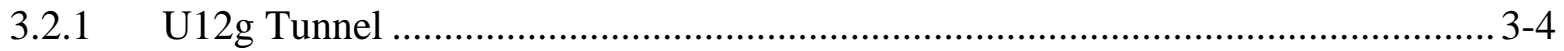

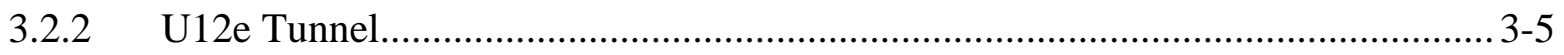

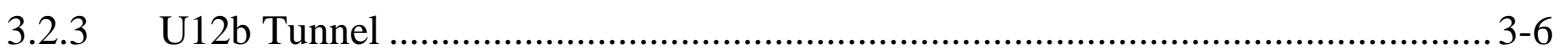

3.2.4 U12n Tunnel .........................................................................................

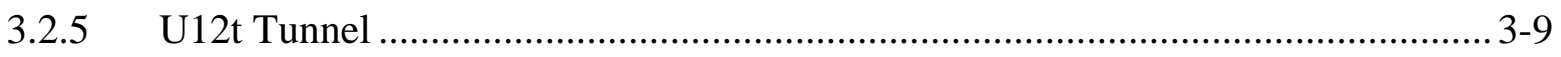

3.2.6 U12p Tunnel ......................................................................................

3.3 Conclusions about Faults Observed in Tunnels ........................................................ 3-11

4.0 Conclusions Concerning Fault Abundances and Extents .................................................. 4-1

4.1 Abundance of Faults at Rainier Mesa .......................................................................... 4-1

4.2 Height of Faults ................................................................................................... 4-1

4.3 Lower Extent of Faults ..................................................................................

4.4 Fault Length ............................................................................................................ 4-3

5.0 Causes of Faulting at Rainier Mesa ........................................................................ $5-1$

6.0 Summary and Conclusions ......................................................................................... 6-1

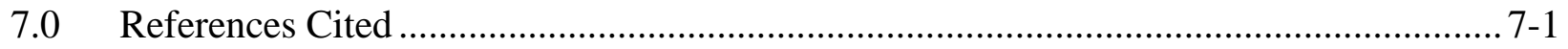

Distribution List 


\section{List of Figures}

\section{NOTE: Figures are located at the end of each section.}

Number

Title

1-1 Map Showing Location of the Rainier Mesa-Shoshone Mountain Model Area

2-1 Generalized Geologic Map of the Rainier Mesa-Shoshone Mountain Model Area

2-2 Geologic Map of the Rainier Mesa and Aquaduct Mesa Area

2-3 Simplified Stratigraphic Section for Rainier Mesa

3-1 Geologic Map of the Shoshone Mountain Area

3-2 Geologic Map of the Halfpint Range

3-3 Schematic Stratigraphic and Geomechanical Column for Rainier and Aqueduct Mesas

3-4 Generalized Geologic Map of the Rainier Mesa Area Showing Locations of Tunnel Complexes

3-5 Reference Map for U12g Tunnel Showing Locations of Mined Drifts and Transect Line

3-6 Reference Map for U12e Tunnel Showing Locations of Mined Drifts and Transect Line

3-7 Reference Map for U12b Tunnel Showing Locations of Mined Drifts and Transect Line

3-8 Reference Map for U12n Tunnel Showing Locations of Mined Drifts and Transect Line

3-9 Simplified Map of U12n Tunnel Showing Drifts (green) and Fault Traces (black)

3-10 Generalized Geologic Map of the Rainier Mesa Area Showing Average Strike of Faults (relative to north) in Tunnel Complexes

3-11 Southwest-Northeast Geologic Cross Section A-A’ through Well ER-12-3, Showing Geologic Setting near U12e, U12b, and U12n Tunnels

3-12 Reference Map for U12t Tunnel Showing Locations of Mined Drifts and Transect Lines

3-13 Simplified Map of U12t Tunnel Showing Drifts (green) and Fault Traces (black)

3-14 Northwest-Southeast Geologic Cross Section through Well ER-12-4 Showing Geologic Setting near U12t Tunnel

3-15 Reference Map for U12p Tunnel Showing Locations of Mined Drifts and Transect Lines

4-1 Fault Station N-21BP-1 (U12n Tunnel)

4-2 Fault Station N-21LOS-1 (U12n Tunnel)

4-3 Fault Station N-21LOS-2 (U12n Tunnel)

4-4 Southwest-Northeast Hydrogeologic Cross Section C-C’ through Well ER-12-3 


\section{List of Tables}

Number

3-1 Quaternary, Tertiary, and Mesozoic Stratigraphic Units of the Rainier MesaAqueduct Mesa Area ………………………………………...................................... 3-3

3-2 Fault Data for U12g Tunnel .................................................................................. 3-5

3-3 Fault Data for U12e Tunnel................................................................................. 3-6

3-4 Fault Data for U12b Tunnel .................................................................................. 3-7

3-5 Fault Data for U12n Tunnel ........................................................................... 3-8

3-6 Fault Data for U12t Tunnel ............................................................................. 3-10

4-1 Faults in the Rainier Mesa-Aqueduct Mesa Area That Are Included in the Rainier Mesa-Shoshone Mountain Hydrostratigraphic Framework Model 


\section{List of Acronyms and Abbreviations}

\begin{tabular}{|c|c|}
\hline AA & alluvial aquifer \\
\hline ATCU & argillic tuff confining unit \\
\hline $\mathrm{B} \& \mathrm{R}$ & basin and range \\
\hline $\mathrm{BN}$ & Bechtel Nevada \\
\hline BRA & Belted Range aquifer \\
\hline BRT & belted range thrust \\
\hline CA & carbonate aquifer \\
\hline CAU & corrective action unit \\
\hline CCU & clastic confining unit \\
\hline $\mathrm{cm}$ & centimeter(s) \\
\hline $\mathrm{E}$ & east \\
\hline $\mathrm{ft}$ & foot (feet) \\
\hline GCU & granite confining unit \\
\hline HFM & hydrostratigraphic framework model \\
\hline HGU & hydrogeologic unit \\
\hline HSU & hydrostratigraphic unit \\
\hline in. & inch(es) \\
\hline LCCU & lower clastic confining unit \\
\hline LCCU1 & lower clastic confining unit - thrust plate \\
\hline LCA3 & lower carbonate aquifer - thrust plate \\
\hline LTCU & lower tuff confining unit \\
\hline $\mathrm{m}$ & meter(s) \\
\hline Ма & millions of years ago \\
\hline $\mathrm{N}$ & north \\
\hline $\mathrm{NE}$ & northeast \\
\hline NSTec & National Security Technologies, LLC \\
\hline NNSAS/NSO & $\begin{array}{l}\text { U.S. Department of Energy, National Nuclear Security Administration Nevada } \\
\text { Site Office }\end{array}$ \\
\hline NNSS & Nevada National Security Site \\
\hline NTS & Nevada Test Site \\
\hline OSBCU & Oak Springs Butte confining unit \\
\hline $\mathrm{RM}$ & Rainier Mesa \\
\hline $\mathrm{RM}-\mathrm{SM}$ & Rainier Mesa-Shoshone Mountain \\
\hline $\mathrm{S}$ & south \\
\hline TCU & tuff confining unit \\
\hline
\end{tabular}




\section{List of Acronyms and Abbreviations (continued)}

TD total depth

TM-LVTA Timber Mountain lower vitric-tuff aquifer

TM-WTA Timber Mountain welded-tuff aquifer

UGT underground nuclear test

UGTA Underground Test Area

USGS U.S. Geological Survey

VTA vitric-tuff aquifer

W west

WP working point

WTA welded-tuff aquifer

WTP weapons testing program 
This page intentionally left blank. 


\subsection{Introduction}

\subsection{Purpose}

Rainier Mesa and Aqueduct Mesa are part of the Rainier Mesa-Shoshone Mountain Corrective Action Unit, or RM-SM CAU, at the Nevada National Security Site (NNSS; formerly known as the Nevada Test Site) (Figure 1-1). For purposes of this paper, Rainier and Aqueduct Mesas are collectively referred to as Rainier Mesa (RM). Scientists are developing models of groundwater flow and contaminant transport for the CAU in support of the U.S. Department of Energy, National Nuclear Security Administration Nevada Site Office (NNSA/NSO) Underground Test Area (UGTA) Sub-Project. Two of these models are being constructed at the sub-CAU level for U12n and U12t Tunnels (N-Tunnel and T-Tunnel), and results of these efforts will be incorporated into the larger RM-SM CAU model.

The proper modeling of the character and extent of faults is expected to be important in the final outcome of the modeling process, and there has been much discussion within the UGTA modeling group regarding the nature of faults at Rainier Mesa. The National Security Technologies, LLC (NSTec), UGTA geology group has been providing data on faults and fractures to the modelers, but these have been limited mainly to observations made at one horizon - the tunnel elevation. There is a need to develop a conceptual model for the nature and extent of faulting in the RM area that incorporates an understanding, with accompanying interpretations of the vertical and lateral extents, of faults that intersect RM tunnels.

The purpose of this report is to document observations on faulting from the six main tunnel complexes in Rainier Mesa that led to the NSTec hypothesis on the nature and extent of faults in this area.

\subsection{Hypothesis for Fault Extents in Rainier Mesa}

Evaluation of the geologic setting and field observations (summarized in the following sections) indicates that most of the faults on RM do not extend into the underlying pre-Tertiary units and fault displacement is not greater at depth. Furthermore, based on rock strength measurements and field mapping observations, it seems reasonable that the uppermost reaches of these faults terminate within the weaker vitric tuffs between the base of the Rainier Mesa Tuff and the upper level of zeolitization.

\subsection{Background Information}

The fault discussions naturally include debate over their possible extents, including length and upper and lower limits. One approach to quantifying fault dimensions has been to apply rock mechanics models, which factor in rock type and strength to predict fault dimensions (e.g., Nicol et al., 1996; Scholz, 2005). Most of this work is based on studies of faulting in rock types different from the rocks in which the tunnels of Rainier Mesa have been mined. This method has promise and should be explored further using properties for lithologies specific to the 
NNSS, that is, zeolitic bedded tuff. While this avenue is being explored, we offer some geologic insights and direct observations that may also help quantify fault dimensions.

The locations and characteristics of RM faults are known mainly from exposures at the surface and in the mined tunnel complexes and core holes in Rainier Mesa. These data points were used historically to construct maps and cross sections that show interpretations of the lateral and vertical extents of faults in support of containment evaluation for underground nuclear testing. These interpretations were understood to represent the most conservative scenarios to illustrate the maximum possible extent of potential pathways for radionuclide transport in the event of failure of the containment systems. It should be noted that the potential for radionuclide transport during the weapons testing program (WTP) was in the near-field environment and under extreme stress conditions. At the time of an underground nuclear test (UGT), any discontinuity could briefly become a pathway. These historical interpretations likely overestimate the vertical extent of most faults. These interpretations may also overestimate the lateral fault extents, but they may arbitrarily show lateral extents that are underestimates (for some faults) due to the limited areas covered by the base maps used to present the geologic data at the tunnel elevation.

UGTA sub-CAU modelers have used these historic maps and cross sections to develop their hydrologic models, and thus are using interpretive data that may not stand up to more realistic interpretations. We hope to show in the following sections why our hypothesis on fault extent may be a better one to use for UGTA models of Rainier Mesa. 


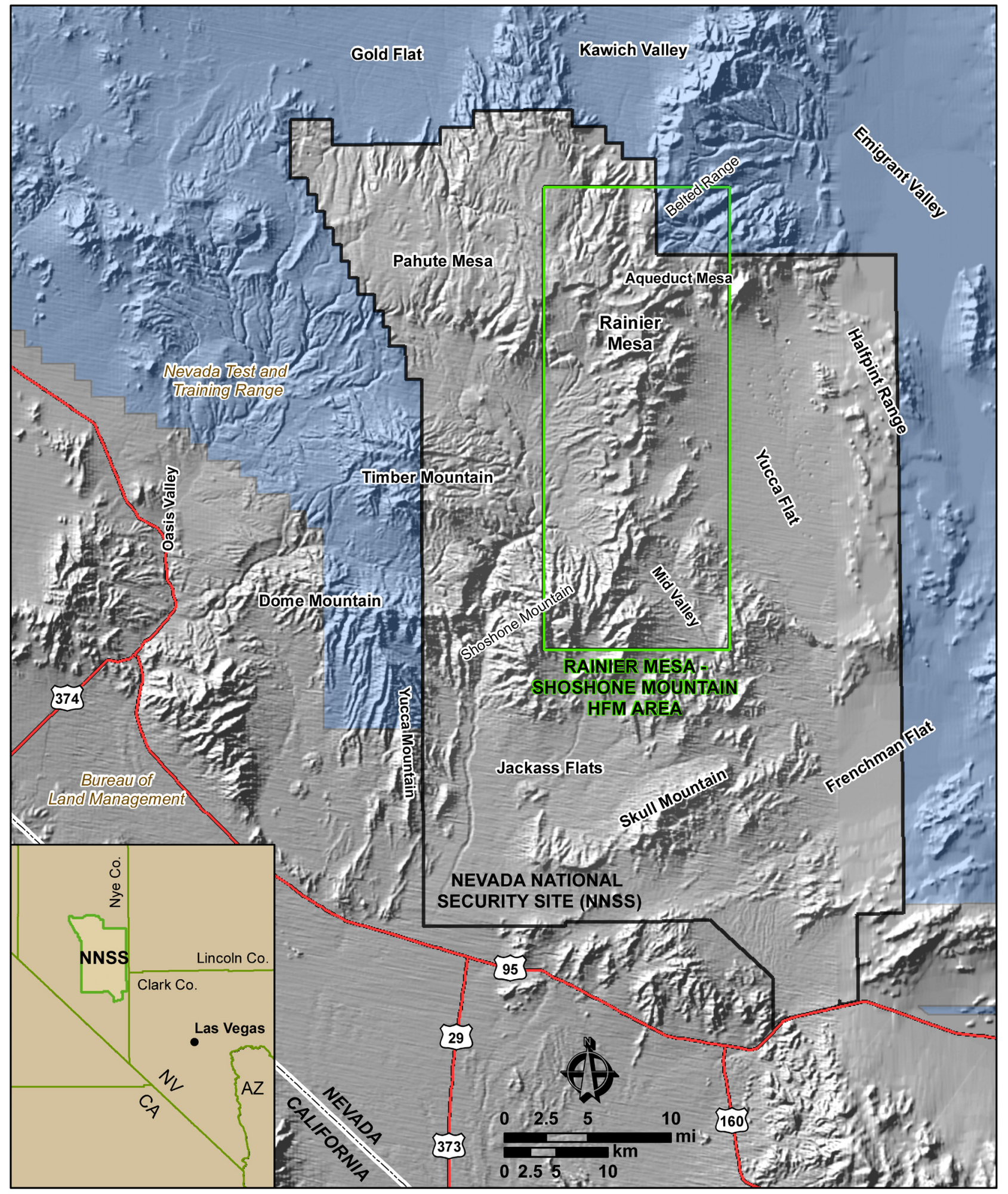

Figure 1-1

Map Showing Location of the Rainier Mesa-Shoshone Mountain Model Area 
This page intentionally left blank. 


\subsection{Geologic and Structural Setting}

Rainier Mesa consists of a thick sequence of Miocene volcanic rocks erupted between 11.45 and 15.90 million years ago (Ma) from large calderas located nearby to the west (Sawyer et al., 1994) (Figure 2-1). Rainier Mesa is capped by welded ash-flow tuff, and the underlying volcanic rocks consist mainly of highly bedded sequences of nonwelded ash-fall and reworked deposits and lesser intercalated welded ash-flow tuffs (Gibbons et al., 1963) (Figures 2-2 and 2-3). The volcanic glass in the lower bedded tuffs has undergone significant in-situ alteration to zeolite minerals as a result of water percolating through the tuffs. In most places, the lower zeolitized section is overlain by a section of vitric bedded tuff, which lies just below the welded-tuff caprock (Sargent and Orkild, 1973).

The volcanic rocks at Rainier Mesa are draped unconformably over an irregular substrate of Paleozoic and late Precambrian sedimentary and Mesozoic intrusive rocks (NSTec, 2007). The volcanic rocks fill a north- to northeast-trending paleo-valley formed in the pre-Tertiary surface. This has resulted in a low amplitude synclinal form in the volcanic rocks that cap the mesa, and generally higher and more variable stratigraphic dips associated with the older volcanic units, as compared with the younger units (Gibbons et al., 1963).

Paleozoic and late Precambrian sedimentary rocks in the area show considerable contractional deformation related to generally east-directed regional thrusting and folding that is older than 100 Ma in the Rainier Mesa area (Gibbons et al., 1963; Cole and Cashman, 1999). The overlying and much younger volcanic rocks show considerably less structural deformation. Although situated within the highly extended Basin and Range province, the Rainier Mesa area is only minimally extended (Drellack et al., 2008; NSTec, 2008; Sawyer et al., 1994), and thus faults within the volcanic rocks at Rainier Mesa are relatively sparse (Gibbons et al., 1963) (Figure 2-2). 
This page intentionally left blank. 


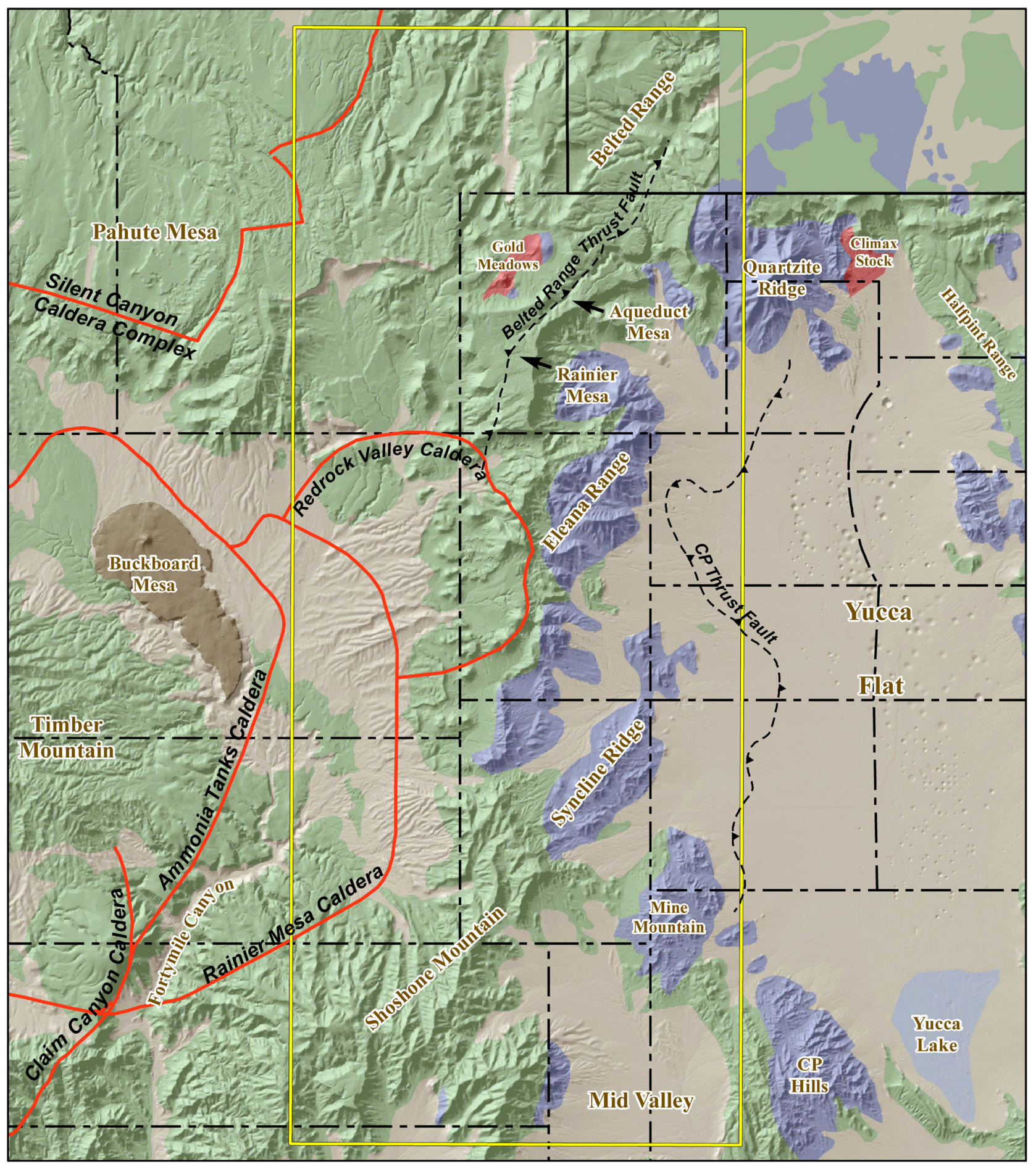

Quaternary playa deposits

Pliocene basaltic rocks

Quaternary/Tertiary alluvial sediments

$\square$ RM-SM boundary

Tertiary volcanic rocks

_ _ $\perp$ Thrust fault, teeth on up-thrown side

Caldera structural margin (buried)

Mesozoic granitic rocks

- NNSS boundary

Paleozoic and Precambrian sedimentary rocks

Surface units from Nevada Bureau of Mines and Geology, 1996

Figure 2-1

Generalized Geologic Map of the Rainier Mesa-Shoshone Mountain Model Area 


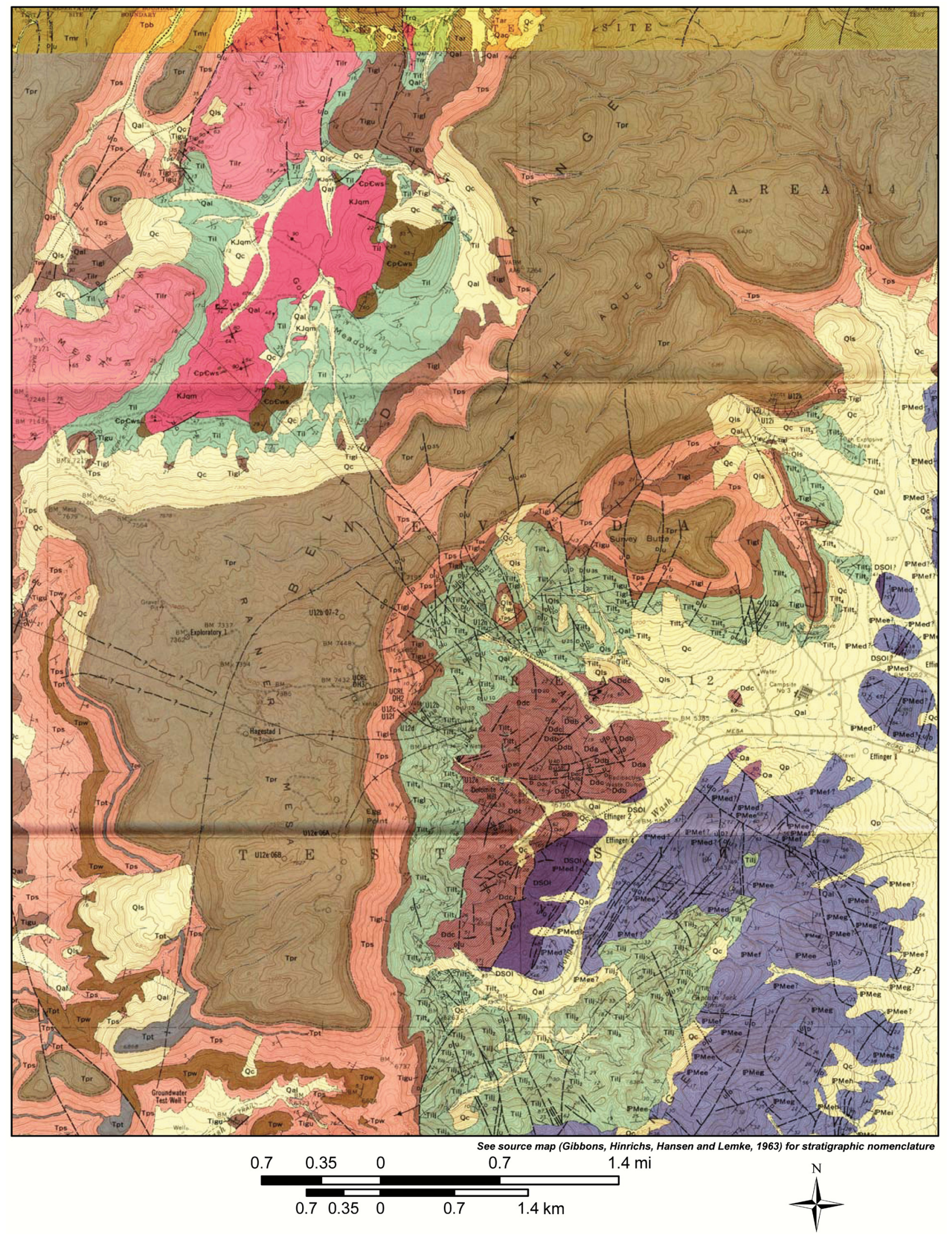

Figure 2-2

Geologic Map of the Rainier Mesa and Aqueduct Mesa Area

(from Gibbons et al., 1963) 


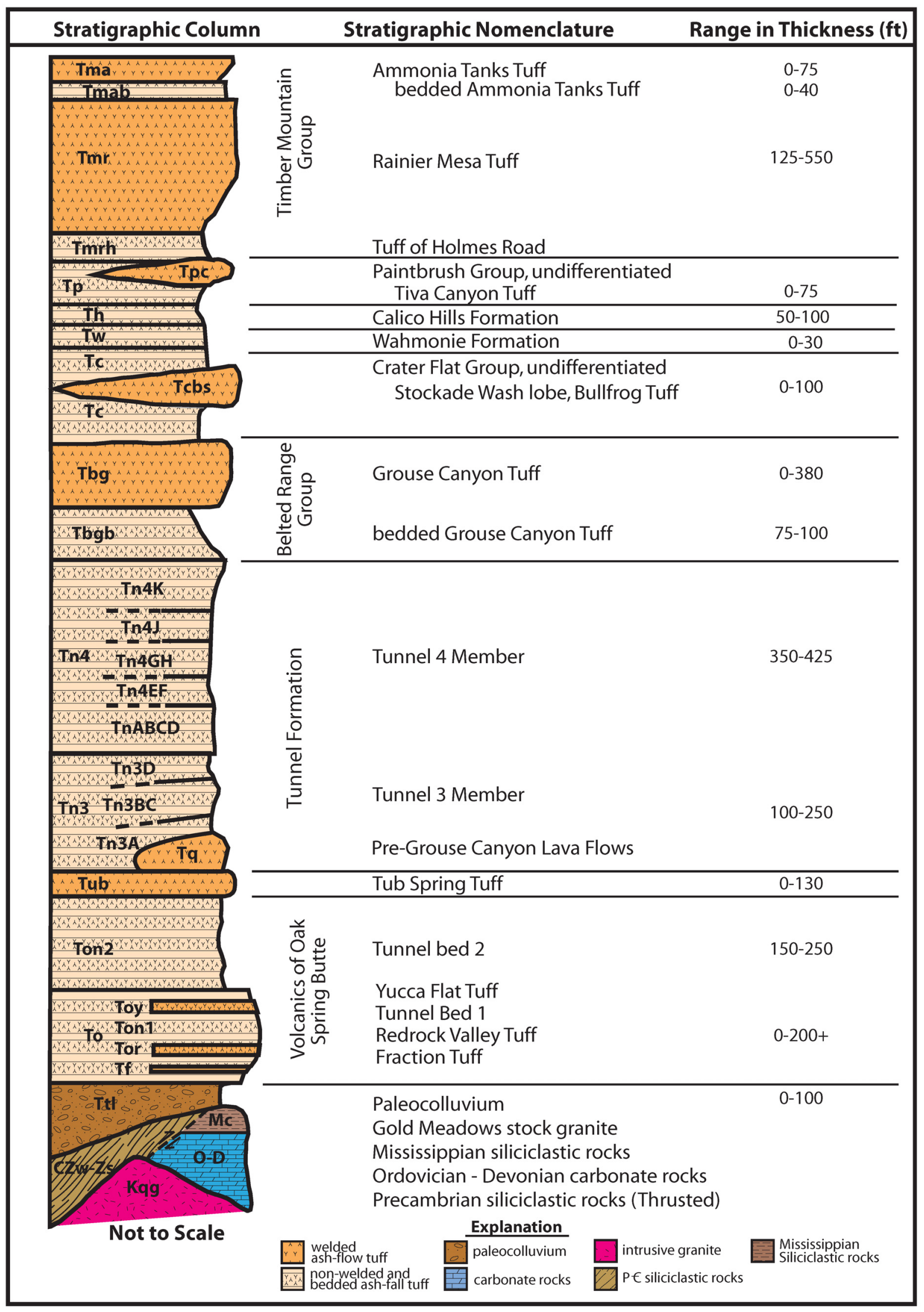

Figure 2-3 Simplified Stratigraphic Section for Rainier Mesa 
This page intentionally left blank. 


\subsection{Observations}

Several types of observations, both on outcrops and in tunnels and drill holes, provide information on the character of faults in RM. Following is a summary of data for faults mapped in outcrop and in RM tunnels.

\subsection{Surface Faults}

Surface faults offsetting volcanic rocks are relatively sparse in the Rainier Mesa area, particularly compared with more extended areas to the east and south. Most faults within the volcanic rocks occur in the vicinity of the "isthmus" between Rainier and Aqueduct Mesas, and are mostly confined to the older zeolitic units (i.e., pre-Grouse Canyon Tuff [green unit in Figure 2-2]), although a few faults offset the Ammonia Tanks and Rainier Mesa Tuffs, which are the youngest cap rock units (brown unit labeled “Tpr” in Figure 2-2). The strikes of faults within volcanic units rotate clockwise from approximately N45W to N-S as one moves northward from the east flank of Rainier Mesa to Aqueduct Mesa. This change in orientation likely reflects temporal changes in the stress field (Minor, 1989), but may also reflect local perturbations in the stress field, possibly related to underlying paleo-topography or the Gold Meadows stock. Measured displacements along surface faults cutting volcanic rocks are less than 15.2 meters (m) (50 feet [ft]), which is reflected in the relatively short lengths of the faults (Gibbons et al., 1963).

Even accounting for the relatively small area, the scarcity of faults at Rainier Mesa is notable. The main reason for the scarcity of faults at Rainier Mesa is that the area has only been minimally extended by syn- and post-volcanic basin-and-range (B\&R) tectonism (Sawyer et al., 1994). It remains today a high volcanic plateau, at approximately 2,134 to $2,286 \mathrm{~m}$ (7,000 to $7,500 \mathrm{ft}$ ) elevation, and capped by generally flat-lying Timber Mountain units. This is in stark contrast to the Yucca Flat extensional basin only a few miles to the southeast, at approximately 1,280 m (4,200 ft) elevation, where Timber Mountain units occur hundreds of meters below the surface and dip up to 12 degrees (Figure 2-2 in Bechtel Nevada [BN], 2006). This difference of over 1,220 m (4,000 ft) resulted primarily from down-dropping and tilting of the Yucca Flat basin along large east-dipping normal faults with hundreds of meters of displacement, mainly after the eruption of the Ammonia Tanks Tuff (BN, 2006).

The minimally extended terrain in north-central NNSS includes Rainier and Aqueduct Mesas, the Eleana Range to the southeast, Quartzite Ridge, and Climax Stock to the east (Figure 2-1). This terrain is defined on the basis of its low density of faults and low stratal tilt observed in the younger volcanic rocks (i.e., Timber Mountain Group) of the region. The transition to more extended terrain in the south occurs near Shoshone Mountain, where faults become more numerous and stratal tilts are greater in the younger volcanic rocks (Drellack et al., 2008; NSTec, 2008) (Figure 3-1). Large calderas to the west define the western boundary of the minimally extended terrain. 
The Gold Meadows granitic intrusive, which is exposed just north of RM, may have contributed, at least in part, to the stability of the RM area by helping to anchor the area during B\&R extension. The Gold Meadows stock was emplaced about $100 \mathrm{Ma}$, long before B\&R extension. Yet very few faults are mapped in either the Gold Meadows stock or the Climax stock to the east, implying some resistance to B\&R faulting.

Faults within pre-Tertiary rocks exposed along the east flank of Rainier Mesa are generally more abundant than in volcanic rocks (Figure 2-2). Although the orientation of faults is somewhat variable in the pre-Tertiary rocks, faults oriented NE, which is a direction different than that for most faults within the volcanic rocks, seem to be dominant. Caution should be exercised, however, when comparing faults within the two rock types because the pre-Tertiary rocks have been subjected to intense pre-volcanic contractional deformation (Cole and Cashman, 1999).

Very few faults in the Rainer Mesa area are observed to offset both pre-Tertiary and volcanic units. Although this is certainly related in part to temporal differences in deformation, it is still in stark contrast to more extended areas to the southeast such as the Halfpint Range, where numerous individual normal faults displace both pre-Tertiary sedimentary rocks and Miocene volcanic rocks, including the Rainier Mesa and Ammonia Tanks tuffs (Figure 3-2).

The distribution of surface faults in the Rainier Mesa vicinity suggests that fault development is strongly dependent on rock type. This is particularly evident in the volcanic rocks, where considerably more faults occur within the older zeolitic units than the overlying unaltered rocks. Although the distribution of faults may simply reflect temporal differences in development, a geomechanical evaluation of the rocks in the Rainier Mesa vicinity shows that the stratigraphic sequence can be grouped within five distinct geomechanical layers (Figure 3-3). Although the Rainier Mesa area has experienced only minimal syn- and post-volcanic extension, the rocks were likely stressed during caldera formation to the west and basin formation to the east. Strain from these events was likely accommodated differently within the different geomechanical layers, resulting in different fault characteristics for various units.

\subsection{Tunnel Observations}

Observations from the main tunnel complexes are presented in separate subsections below. The observations are listed for each of the six main tunnel complexes (Figure 3-4), and compare fault

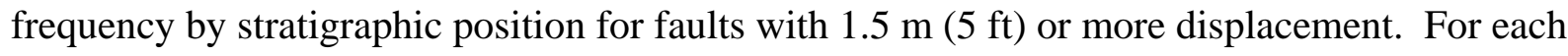
tunnel complex, a transect was selected that is at a high angle to the strikes of mapped faults in the area. The number of faults mapped in drifts and drill holes along the transect is listed by stratigraphic unit. The data for each tunnel are followed by statements about the general fault characteristics for that tunnel. The data are presented in order from the southern-most tunnel in RM, U12g Tunnel, to the northern-most, U12p Tunnel.

Tunnel 4 Member (Tn4) was subdivided for this analysis because there are significant lithologic differences between the more thin-bedded and variable lower subunits (Tn4A-F) and the more massive upper ones (Tn4G-K) (Table 3-1 and Figure 2-3). 
Table 3-1

Tertiary and Mesozoic Stratigraphic Units of the Rainier Mesa-Aqueduct Mesa Area

\begin{tabular}{|c|c|}
\hline Stratigraphic Assemblages and Major Units ${ }^{a, b}$ & Volcanic Sources $^{c}$ \\
\hline $\begin{array}{l}\text { Quaternary and Tertiary Sediments } \\
\text { Young alluvium (Qay) } \\
\text { Quaternary-Tertiary colluvium (QTC) } \\
\text { Intermediate alluvium (Qai) } \\
\text { Quaternary-Tertiary alluvium (QTa) } \\
\end{array}$ & Not applicable \\
\hline $\begin{array}{l}\text { Timber Mountain Group (Tm) } \\
\text { Ammonia Tanks Tuff (Tma) } \\
\text { bedded Ammonia Tanks Tuff (Tmab) } \\
\text { Rainier Mesa Tuff (Tmr) } \\
\text { tuff of Holmes Road (Tmrh) } \\
\end{array}$ & $\begin{array}{l}\text { Timber Mountain Caldera Complex } \\
\text { Ammonia Tanks Caldera } \\
\text { Rainier Mesa Caldera }\end{array}$ \\
\hline $\begin{array}{l}\text { Paintbrush Group (Tp) } \\
\text { Tiva Canyon Tuff (Tpc) }\end{array}$ & Claim Canyon Caldera \\
\hline Calico Hills Formation (Th; formerly Tac) & Unknown \\
\hline $\begin{array}{l}\text { Wahmonie Formation (Tw) } \\
\text { tuff of Wahmonie Flat (Twlb) }\end{array}$ & Wahmonie Volcanic Center \\
\hline $\begin{array}{l}\text { Crater Flat Group (Tc) } \\
\text { Prow Pass Tuff (Tcp) } \\
\text { Bullfrog Tuff (Tcb) } \\
\text { Stockade Wash lobe (Tcbs) } \\
\text { Tram Tuff (Tct) } \\
\text { Belted Range Group (Tb) } \\
\text { Deadhorse Flat Formation (Tbd) } \\
\text { Grouse Canyon Tuff (Tbg) } \\
\end{array}$ & $\begin{array}{l}\text { Silent Canyon Caldera Complex } \\
\text { Area } 20 \text { Caldera } \\
\text { Grouse Canyon Caldera } \\
\end{array}$ \\
\hline $\begin{array}{c}\text { Tram Ridge Group (Tr) } \\
\text { Lithic Ridge Tuff (Trl) }\end{array}$ & Unknown \\
\hline $\begin{array}{l}\text { Tunnel Formation (Tn) } \\
\text { Tunnel } 4 \text { Member (Tn4) } \\
\text { beds 4K (Tn4K) } \\
\text { beds 4J (Tn4J) } \\
\text { beds 4H (Tn4H) } \\
\text { beds 4G (Tn4G) } \\
\text { beds 4F (Tn4F) } \\
\text { beds 4E (Tn4E) } \\
\text { beds 4CD (Tn4CD) } \\
\text { beds 4AB (Tn4AB) } \\
\text { Tunnel 3 Member (Tn3) } \\
\text { beds 3D (Tn3D) } \\
\text { beds 3BC (Tn3BC) } \\
\text { beds 3A (Tn3A) }\end{array}$ & Unknown \\
\hline
\end{tabular}


Table 3-1

Tertiary and Mesozoic Stratigraphic Units of the

Rainier Mesa-Aqueduct Mesa Area (continued)

\begin{tabular}{|c|c|}
\hline Stratigraphic Assemblages and Major Units ${ }^{\text {a, b }}$ & Volcanic Sources ${ }^{c}$ \\
\hline $\begin{array}{c}\text { Volcanics of Big Dome (Tu) } \\
\text { Tub Spring Tuff (Tub) }\end{array}$ & Unknown \\
\hline $\begin{array}{l}\text { Volcanics of Oak Spring Butte (To) } \\
\text { tunnel bed } 2 \text { (Ton2) } \\
\text { Yucca Flat Tuff (Toy) } \\
\text { tunnel bed } 1 \text { (Ton1) } \\
\text { Redrock Valley Tuff (Tor) } \\
\text { tuff of Twin Peaks (Tot) } \\
\text { Older Volcanics, undivided (To) } \\
\end{array}$ & $\begin{array}{c}\text { Unknown } \\
\text { Redrock Valley Caldera } \\
\text { Unknown }\end{array}$ \\
\hline $\begin{array}{l}\text { Paleocolluvium (TI) } \\
\text { Paleocolluvium, undivided }\end{array}$ & Not applicable \\
\hline $\begin{array}{l}\text { Plutonic Rocks (Kg) } \\
\text { Gold Meadows stock (Kgg) }\end{array}$ & Not applicable \\
\hline
\end{tabular}

a Compiled from Slate et al. (1999) and Ferguson et al. (1994).

b Letters in parentheses are stratigraphic unit map symbols.

c Sources, where known, from Sawyer et al. (1994); Redrock Valley Caldera from NSTec, 2007.

\subsubsection{U12g Tunnel}

A 1,676-m (5,500-ft) long transect was measured across G-Tunnel on a bearing of N70W (at a high angle to average fault trends measured in other tunnel complexes within Rainier Mesa), following the entire length of the original U12g Main drift and the U12g.06 Main drift (Figure 3-5). The distal end of the transect also crosses the U12g.10 drifts.

Three faults with displacements greater than $1.1 \mathrm{~m}$ (3.5 ft) (the criterion for fault displacement

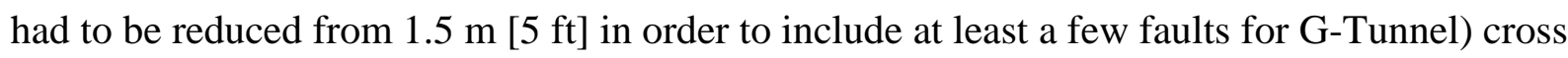
the transect, yielding an apparent fault frequency of approximately one fault per $559 \mathrm{~m}$ $(1,833 \mathrm{ft})$. This number is perhaps slightly misleading, because the strikes of several faults (all of small displacement) in the G-Tunnel area are close to the bearing of the transect. See summary statements following the data table (Table 3-2).

Stratigraphically, this transect begins at the portal in Tunnel bed 2 (Ton2), and continues upsection to the terminus in upper Tunnel Formation, 4 Member, bed 4K (Tn4K) (Figure 2-3). 
Table 3-2

Fault Data for U12g Tunnel

\begin{tabular}{|l|c|c|c|c|}
\hline \multicolumn{1}{|c|}{ Stratigraphic Unit } & $\begin{array}{c}\text { Length of Unit } \\
\text { Exposed } \\
\text { Meters } \\
\text { (feet) }\end{array}$ & $\begin{array}{c}\text { Percentage of } \\
\text { Transect in Which } \\
\text { Unit is Exposed }\end{array}$ & $\begin{array}{c}\text { Fumber of } \\
\text { Faults }\end{array}$ & $\begin{array}{c}\text { Fault } \\
\text { Frequency } \\
\text { per } \mathbf{3 0 0 ~} \mathbf{~ m} \\
\mathbf{( 1 , 0 0 0 ~ f t ) ~ o f ~} \\
\text { Transect }\end{array}$ \\
\hline Tunnel bed 2 (Ton2) & $\begin{array}{c}807.7 \\
(2,650)\end{array}$ & 48 & 3 & 1.13 \\
\hline Tunnel 3 Member (Tn3) & $\begin{array}{c}320.0 \\
(1,050)\end{array}$ & 19 & 0 & $\mathrm{~N} / \mathrm{A}$ \\
\hline $\begin{array}{l}\text { Tunnel 4 Member, beds } \\
\text { 4A-F (Tn4A-F) }\end{array}$ & $\begin{array}{c}152.4 \\
(500)\end{array}$ & 1 & 0 & $\mathrm{~N} / \mathrm{A}$ \\
\hline $\begin{array}{l}\text { Tunnel 4 Member, beds } \\
\text { 4G-K (Tn4G-K) }\end{array}$ & $\begin{array}{c}396.2 \\
(1,300)\end{array}$ & 23 & 0 & $\mathrm{~N} / \mathrm{A}$ \\
\hline \\
a Faults with displacement $>1.1 \mathrm{~m}(3.5 \mathrm{ft})$ & $\begin{array}{c}\text { Overall } \\
\text { Fault } \\
\text { Frequency }\end{array}$ & $\begin{array}{c}\mathbf{0 . 5 4} \\
\mathbf{( 0 . 5 5 )}\end{array}$ \\
\hline
\end{tabular}

\section{Summary Statements for G-Tunnel}

- One fault crosses the U12g Tunnel complex that could be considered a through-going fault; however, this fault does not cross the transect described above. Larger displacement faults found in the U12e Tunnel complex have been projected southward towards G-Tunnel, but only one of these faults was found to generally align with a fault in G-Tunnel (near the portal ends of the U12g.10 and U12g.09 drifts).

- The bearing of the $457-\mathrm{m}$ (1,500-ft) long U12g.09 drifts is N10E, nearly perpendicular to the

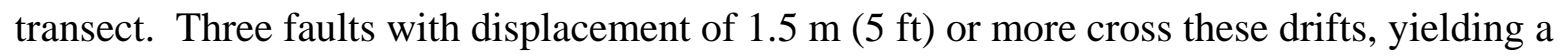
fault frequency of one fault per $152 \mathrm{~m}$ (500 ft), which might be a more accurate estimation of the fault frequency in G-Tunnel as a whole. It should be noted that the average strike of the faults mapped in the U12g.09 drifts is N50W, quite similar to the average fault strike measured in the U12e Tunnel complex.

- The G-Tunnel area is essentially free of larger-displacement (>1.5 m [5 ft]) faults. The U12g.06 experiment, which included a 21.3-m (70-ft) radius hemisphere mined above the 4-m (13-ft) high Main drift, at an angle of 68 degrees above horizontal, was free of faulting throughout (stratigraphically it was mined entirely within Tn4J and Tn4K).

\subsubsection{U12e Tunnel}

A 2,286-m (7,500-ft) long transect was measured across E-Tunnel on a bearing of N60E (approximately perpendicular to average fault trend in E-Tunnel of N45W), following the entire length of the U12e Main drift, the U12e.06 drift, and U12e.06 UG-1 drill hole (Figure 3-6).

Eight faults with displacements of $1.5 \mathrm{~m}(5 \mathrm{ft})$ or more cross this transect, yielding a fault frequency of approximately one fault per $287 \mathrm{~m}$ (940 ft) (Table 3-3). 
Stratigraphically, this transect begins at the portal, near the contact between the Devonian dolomite and tunnel bed 1 (Ton1), and proceeds up-section, with the exception of a small depositional syncline near 1,392 m (4,500 ft), to the terminus in Tn4K (Figure 2-3).

Table 3-3

Fault Data for U12e Tunnel

\begin{tabular}{|l|c|c|c|c|}
\hline \multicolumn{1}{|c|}{ Stratigraphic Unit } & $\begin{array}{c}\text { Length of Unit } \\
\text { Exposed } \\
\text { Meters } \\
\text { (feet) }\end{array}$ & $\begin{array}{c}\text { Percentage of } \\
\text { Transect in Which } \\
\text { Unit is Exposed }\end{array}$ & $\begin{array}{c}\text { Number of } \\
\text { Faults }\end{array}$ & $\begin{array}{c}\text { Fault } \\
\text { Frequency } \\
\text { per 300 m } \\
\mathbf{1} \mathbf{1 , 0 0 0} \mathbf{~ f t ) ~ o f ~} \\
\text { Transect }\end{array}$ \\
\hline Tunnel Bed 1 (Ton1) & $\begin{array}{c}305 \\
(1,000)\end{array}$ & 13 & 0 & $\mathrm{~N} / \mathrm{A}$ \\
\hline Tunnel Bed 2 (Ton2) & $\begin{array}{c}502.9 \\
(1,650)\end{array}$ & 22 & 1 & 0.61 \\
\hline Tunnel 3 Member (Tn3) & $\begin{array}{c}411.5 \\
(1,350)\end{array}$ & 18 & 1 & 0.74 \\
\hline $\begin{array}{l}\text { Tunnel 4 Member, beds A-F } \\
\text { (Tn4A-F) }\end{array}$ & $\begin{array}{c}198.1 \\
(650)\end{array}$ & 9 & 2 & 3.08 \\
\hline $\begin{array}{l}\text { Tunnel 4 Member, beds 4G-K } \\
\text { (Tn4G-K) }\end{array}$ & $\begin{array}{c}868.7 \\
(2,850)\end{array}$ & 38 & 4 & 1.4 \\
\hline \multicolumn{2}{|l|}{ a Faults with displacement >1.5 m (5 ft) } & & $\begin{array}{c}\text { Overall } \\
\text { Fault } \\
\text { Frequency }\end{array}$ & $\begin{array}{c}\mathbf{1 . 0 5} \\
\mathbf{( 1 . 0 7 )}\end{array}$ \\
\hline
\end{tabular}

\section{Summary Statements for E-Tunnel}

- Only three of the faults crossing this transect could conservatively be considered throughgoing between two or more tunnel complexes $(1,265,1,600$, and 2,164 $\mathrm{m}[4,150,5,250$, and $7,100 \mathrm{ft}]$ in length).

- The strikes of the faults that occur under the topographic edge of the mesa, that is, beyond approximately $975 \mathrm{~m}$ (3,200 ft) on the transect, generally trend N45W. However the smaller displacement faults that occur between the portal and $975 \mathrm{~m}(3,200 \mathrm{ft})$ into the tunnel have a general strike of $\mathrm{N}-\mathrm{S}$, which is approximately parallel to the edge of the mesa.

- An examination of the complex as a whole would suggest that fault frequency is slightly greater below Tn4G than above. Data from two drift complexes with similar bearings and lengths support this conclusion. Considering all faults (regardless of displacement), the U12e.04 drift (549 m [1,800 ft] long), mined in lower Tn4 and Tn3, has nine mapped faults, and the U12e.11 drift (457 m [1,500 ft] long), mined in upper Tn4, has only four mapped faults.

\subsubsection{U12b Tunnel}

A 914-m (3,000-ft) long transect was measured through B-Tunnel on a bearing of N65W, following the entire length of the U12b Access drift (Figure 3-7). This is approximately parallel 
to the average fault trends in the U12e Tunnel (N45W, south of B-Tunnel), and at a higher angle to the average fault trends measured in the U12n Tunnel (N20-30W, immediately north of B-Tunnel).

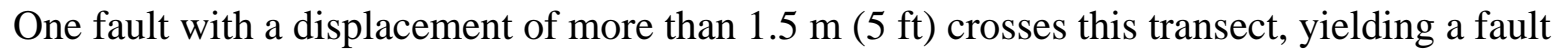
frequency of one fault per $914 \mathrm{~m}$ (3,000 ft) (Table 3-4).

Stratigraphically, this transect begins at the portal in upper Tn4, and continues up-section through bedded Grouse Canyon Tuff (Tbgb) and welded Tbg, and terminates in bedded tuffs of the post-Tbg-pre-Rainier Mesa Tuff (Tmr) (known as "Paintbrush Tuff” during the era of testing in Rainier Mesa) (Figure 2-3). Some sections of the "Paintbrush" (near a synclinal axis, including a part of U12b.10 drifts) on this transect are above the upper level of pervasive zeolitization.

Table 3-4

Fault Data for U12b Tunnel

\begin{tabular}{|c|c|c|c|c|}
\hline Stratigraphic Unit & $\begin{array}{l}\text { Length of Unit } \\
\text { Exposed } \\
\text { Meters } \\
\text { (feet) }\end{array}$ & $\begin{array}{c}\text { Percentage of } \\
\text { Transect }^{\mathrm{a}} \text { in } \\
\text { Which Unit is } \\
\text { Exposed }\end{array}$ & $\begin{array}{l}\text { Number of } \\
\text { Faults }\end{array}$ & $\begin{array}{c}\text { Fault } \\
\text { Frequency } \\
\text { per } 300 \mathrm{~m} \\
(1,000 \mathrm{ft}) \text { of } \\
\text { Transect }\end{array}$ \\
\hline Tunnel 4 Member (Tn4) & $\begin{array}{c}57.9 \\
(190)\end{array}$ & 6 & 0 & N/A \\
\hline $\begin{array}{l}\text { Lower Grouse Canyon } \\
\text { Formation (Tbgb) }\end{array}$ & $\begin{array}{l}106.7 \\
(350)\end{array}$ & 12 & 0 & $\mathrm{~N} / \mathrm{A}$ \\
\hline $\begin{array}{l}\text { Grouse Canyon Formation } \\
\text { (Tbg) (welded ash-flow tuff) }\end{array}$ & $\begin{array}{c}39.6 \\
(130)\end{array}$ & 4 & 0 & $\mathrm{~N} / \mathrm{A}$ \\
\hline $\begin{array}{l}\text { Post-Tbg, Pre-Tmr tuffs, } \\
\text { zeolitized }\end{array}$ & $\begin{array}{c}496.8 \\
(1,630)\end{array}$ & 54 & 1 & 0.61 \\
\hline $\begin{array}{l}\text { Post-Tbg, Pre-Tmr tuffs, } \\
\text { vitric }\end{array}$ & $\begin{array}{l}213.4 \\
(700)\end{array}$ & 24 & 0 & N/A \\
\hline \multicolumn{3}{|c|}{ 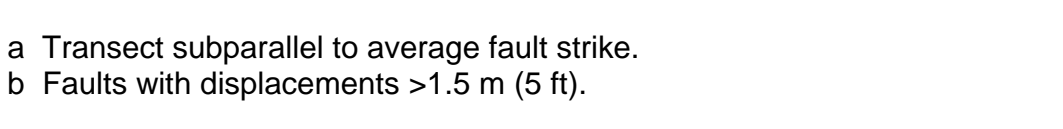 } & $\begin{array}{l}\text { Overall } \\
\text { Fault } \\
\text { Frequency }\end{array}$ & $\begin{array}{c}0.33 \\
(0.33)\end{array}$ \\
\hline
\end{tabular}

\section{Summary Statements for B-Tunnel}

- The bearing of the main B-Tunnel access drift is not ideal to intersect faults that are similar in strike to those in E-Tunnel; however, several drifts mined away from the access tunnel, both north and south (bearings N10-20E) were also free of faulting.

- Several larger displacement faults were mapped in the southern portion of N-Tunnel (approximately $183 \mathrm{~m}$ [600 ft] lower elevation, within zeolitized tuff section), immediately north of the U12b complex. Projection of theses faults along their strikes (well documented across several drifts and drill holes) should have placed them well within the B-Tunnel complex (U12b.10, U12b.08, and U12b.09 drifts, mined above the upper level of pervasive zeolitization). However, there was no evidence of these faults mapped at B-Tunnel. One can 
hypothesize that these faults predate the deposition of the "Paintbrush Tuff" or are confined to zeolitized tuff.

\subsubsection{U12n Tunnel}

A 2,515-m (8,250-ft) long transect was measured across N-Tunnel on an initial bearing of N65W for the first $686 \mathrm{~m}(2,250 \mathrm{ft})$, then continuing at a bearing of $\mathrm{E}-\mathrm{W}$ for another 1,829 $\mathrm{m}(6,000 \mathrm{ft})$ along the U12n-Extension drifts (Figure 3-8). These bearings intersect the general fault trend at N-Tunnel (N20-30W) (Figure 3-9) at a high angle. The strike of faults is rotated clockwise from N45W in G-Tunnel to the south, to N20-30W at N-Tunnel (Figure 3-10).

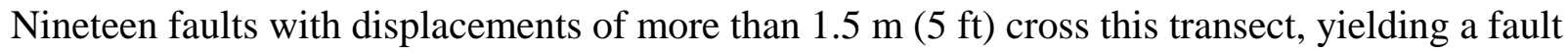
frequency of one fault per $133 \mathrm{~m}$ (435 ft) (Table 3-5).

Stratigraphically, the transect begins in lower Tn3, crosses a depositional anticline through Ton2, then continues up-section, across a depositional syncline through the uppermost part of Tn4

(Figures 2-3 and 3-11).

Table 3-5

Fault Data for U12n Tunnel

\begin{tabular}{|l|c|c|c|c|}
\hline \multicolumn{1}{|c|}{ Stratigraphic Unit } & $\begin{array}{c}\text { Length of Unit } \\
\text { Exposed } \\
\text { Meters } \\
\text { (feet) }\end{array}$ & $\begin{array}{c}\text { Percentage of } \\
\text { Transect in Which } \\
\text { Unit is Exposed }\end{array}$ & $\begin{array}{c}\text { Number of } \\
\text { Faults a }\end{array}$ & $\begin{array}{c}\text { Fault } \\
\text { Frequency } \\
\text { per } \mathbf{3 0 0} \mathbf{~ m} \\
\mathbf{( 1 , 0 0 0} \mathbf{f t} \text { of } \\
\text { Transect }\end{array}$ \\
\hline Tunnel Bed 2 (Ton2) & $\begin{array}{c}487.7 \\
(1,600)\end{array}$ & 20 & 8 & 5 \\
\hline $\begin{array}{l}\text { Tub Spring Formation (Tub, } \\
\text { non-welded) }\end{array}$ & $\begin{array}{c}137.2 \\
(450)\end{array}$ & 5 & 1 & 2.22 \\
\hline Tunnel 3 Formation (Tn3) & $\begin{array}{c}335.3 \\
(1,100)\end{array}$ & 13 & 1 & 0.91 \\
\hline $\begin{array}{l}\text { Tunnel 4 Member, beds A-F } \\
\text { (Tn4A-F) }\end{array}$ & $\begin{array}{c}335.3 \\
(1,100)\end{array}$ & 13 & 6 & 5.45 \\
\hline $\begin{array}{l}\text { Tunnel 4 Member, beds } \\
\text { 4G-K (Tn4G-K) }\end{array}$ & $\begin{array}{c}1,219.2 \\
(4,000)\end{array}$ & 49 & 3 & 0.75 \\
\hline
\end{tabular}

\section{Summary Statements for N-Tunnel}

- Approximately six faults/fault systems crossing this transect can be considered through-going faults. The fault system exposed at approximately 183 to $396 \mathrm{~m}$ (600 to 1,300 ft) in from the portal is a through-going fault that could be conservatively extended to possibly related faults in the pre-Tertiary rocks. This system was also mapped on the surface of the mesa. 
- Average fault strikes in the N-Tunnel area are approximately 20 degrees more northerly than major fault trends mapped in the E-Tunnel complex immediately to the south.

- Statistically, data suggest that fault frequency increases with depth in the stratigraphic section. However, in N-Tunnel, there are apparently a greater number of faults (in the same stratigraphic horizons) in the immediate vicinity of the Gold Meadows intrusive. That is, we cannot be sure whether the increased faulting at tunnel level near the intrusive is a result of proximity to the intrusive or because of the lower stratigraphic position.

- The detailed studies (core drilling, geophysical and geomechanical surveys) made in the U12n.10 MIGHTY EPIC drifts (only a few tens of meters above the pre-Tertiary surface) suggest that the faults seen at tunnel level have no connection with the pre-Tertiary surface configuration. That is, scarps mapped on the pre-Tertiary surface could not be correlated to the known faults at tunnel level, and faults logged in cores of the pre-Tertiary rocks could not be correlated with structures seen at tunnel level.

\subsubsection{U12t Tunnel}

A 2,134-m (7,000-ft) long transect was measured across T-Tunnel on an approximate bearing of N75W, at a high angle to the average fault strike of N05-30E (Figures 3-12 and 3-13), following the U12t Main Drift, the U12t.06 UG-1 drill hole, and projections from the nearby U12t.03 UG-1 drill hole.

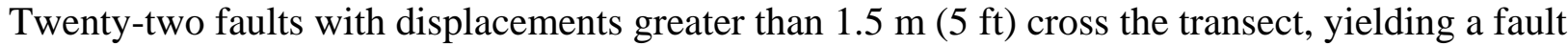
frequency of approximately one fault per $97 \mathrm{~m}$ (318 ft) (Table 3-6).

Stratigraphically, this transect begins at the portal in post-Tbg, pre-Tmr ("Paintbrush Tuff”) bedded tuffs, and continues down-section to the terminus in Ton2 (Figure 2-3).

\section{Summary Statements for T-Tunnel}

- Eight faults that cross this transect could conservatively be considered through-going faults, and two of these are probably better described as "regional" faults (that is, faults with greater than $30.5 \mathrm{~m}$ [100 ft]) of displacement and a well developed surface trace). It is reasonable to consider that these faults are related to structures within the pre-Tertiary rocks (Figure 3-14).

- The strikes of the faults located outside the topographic edge of the mesa (0 to $610 \mathrm{~m}$ $[2,000 \mathrm{ft}]$ from the portal) have strikes that are more variable than those within the mesa proper.

- Faulting does not appear to be more frequent in the lower portion of the stratigraphic section.

- Faults in the central portion of the T-Tunnel complex (U12t.03, U12t.04, and the portal sections of all of the other drifts) are quite discontinuous and irregular in strike and dip, when compared to faults in Rainier Mesa proper (Figure 3-13). Many structures could not be traced 
across a single 3.1-m (10-ft) wide drift, while others change direction of dip and magnitude of displacement over very small distances (slickensides were essentially vertical).

- Several faults in the U12t.04 complex exhibited openings along the planes that were covered by crystalline silica (dry upon excavation).

- Several very small displacement faults (<15.2 cm [0.5 ft]), and fractures with no displacement, produced a considerable volume of water when excavated at the working point (WP) end of the U12t.03 Bypass drift.

- The U12t.02 WP is located relatively low in the stratigraphic section, quite near to a limestone ridge. The drifts are relatively free of faulting, and no structures in the area could be related to the structure of the nearby pre-Tertiary ridge.

Table 3-6

Fault Data for U12t Tunnel

\begin{tabular}{|c|c|c|c|c|}
\hline Stratigraphic Unit & $\begin{array}{l}\text { Length of Unit } \\
\text { Exposed } \\
\text { Meters } \\
\text { (feet) }\end{array}$ & $\begin{array}{l}\text { Percentage of } \\
\text { Transect in Which } \\
\text { Unit is Exposed }\end{array}$ & $\begin{array}{l}\text { Number of } \\
\text { Faults }{ }^{a}\end{array}$ & $\begin{array}{c}\text { Fault } \\
\text { Frequency } \\
\text { per } 300 \mathrm{~m} \\
(1,000 \mathrm{ft}) \text { of } \\
\text { Transect }\end{array}$ \\
\hline $\begin{array}{l}\text { Post-Tbg, Pre-Tmr tuffs, } \\
\text { zeolitized }\end{array}$ & $\begin{array}{l}30.5 \\
(100)\end{array}$ & 1 & 0 & N/A \\
\hline $\begin{array}{l}\text { Lower Grouse Canyon } \\
\text { Formation (Tbgb) }\end{array}$ & $\begin{array}{l}76.2 \\
(250) \\
\end{array}$ & 4 & 0 & N/A \\
\hline $\begin{array}{l}\text { Tunnel } 4 \text { Member, beds } \\
\text { 4G-K (Tn4G-K) }\end{array}$ & $\begin{array}{l}609.6 \\
(2,000)\end{array}$ & 29 & $\begin{array}{c}9 \\
\text { (only } 1 \text { under } \\
\text { caprock) }\end{array}$ & $4.5 / 0.5$ \\
\hline $\begin{array}{l}\text { Tunnel } 4 \text { Member, beds A-F } \\
(T n 4 A-F)\end{array}$ & $\begin{array}{c}914.4 \\
(3,000)\end{array}$ & 42 & 8 & 2.67 \\
\hline Tunnel 3 Formation (Tn3) & $\begin{array}{c}442.0 \\
(1,450)\end{array}$ & 21 & 5 & 3.45 \\
\hline Tunnel bed 2 (Ton2) & $\begin{array}{r}61.0 \\
(200) \\
\end{array}$ & 3 & 0 & $\mathrm{~N} / \mathrm{A}$ \\
\hline \multicolumn{3}{|c|}{ a Faults with displacements $>1.5 \mathrm{~m}(5 \mathrm{ft})$. } & $\begin{array}{c}\text { Overall } \\
\text { Fault } \\
\text { Frequency }\end{array}$ & $\begin{array}{l}3.09 / 1.97 \\
(3.14 / 2.0)\end{array}$ \\
\hline
\end{tabular}

\subsubsection{U12p Tunnel}

The U12p Tunnel complex includes a 914-m (3,000-ft) long access drift (oriented approximately N45W), a 579-m (1,900-ft) long drift (oriented approximately N85W), and a 564-m (1,850-ft)

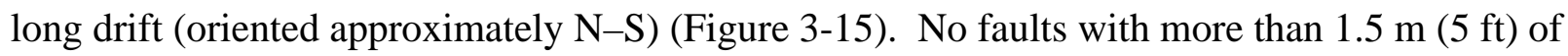
displacement were encountered anywhere within the complex. The entire complex was constructed above the Tbg, within the post-Tbg, pre-Tmr bedded tuffs, quite close to the upper level of zeolitization (Figure 2-3). 


\subsection{Conclusions about Faults Observed in Tunnels}

- The structural setting for Rainier Mesa proper (not including U12t and U12p Tunnels) is generally "simple," that is, there are very few through-going faults with lengths more than a few hundred meters (few thousand feet), and the displacement on most faults is $1.5 \mathrm{~m}$ (5 ft) or less.

- The structural setting at U12t Tunnel is more "complex" than other tunnels (compare Figures 3-11 and 3-14), and is unrelated to that of Rainier Mesa proper. Fault frequency within T-Tunnel is higher than any other tunnel complex, and the variability and discontinuous nature of individual faults is unique. The average strike of faults (N5-30E) is quite different than at U12n Tunnel (N20-30W) (Figure 3-10).

- Given the almost complete lack of faulting seen on the surface of Rainier Mesa proper, and the observations of faults not extending upward into younger subunits or through the vitric rocks, it can be hypothesized that the era of faulting either predates the deposition of the younger units, or the zeolitization of these units, or both, or strain is accommodated through grain-to-grain movement within these weaker units.

- The frequency of faulting appears to increase with proximity to the Gold Meadows intrusive body (at tunnel level, just north of N-Tunnel).

- Very few faults can be correlated with pre-Tertiary structures. 
This page intentionally left blank. 


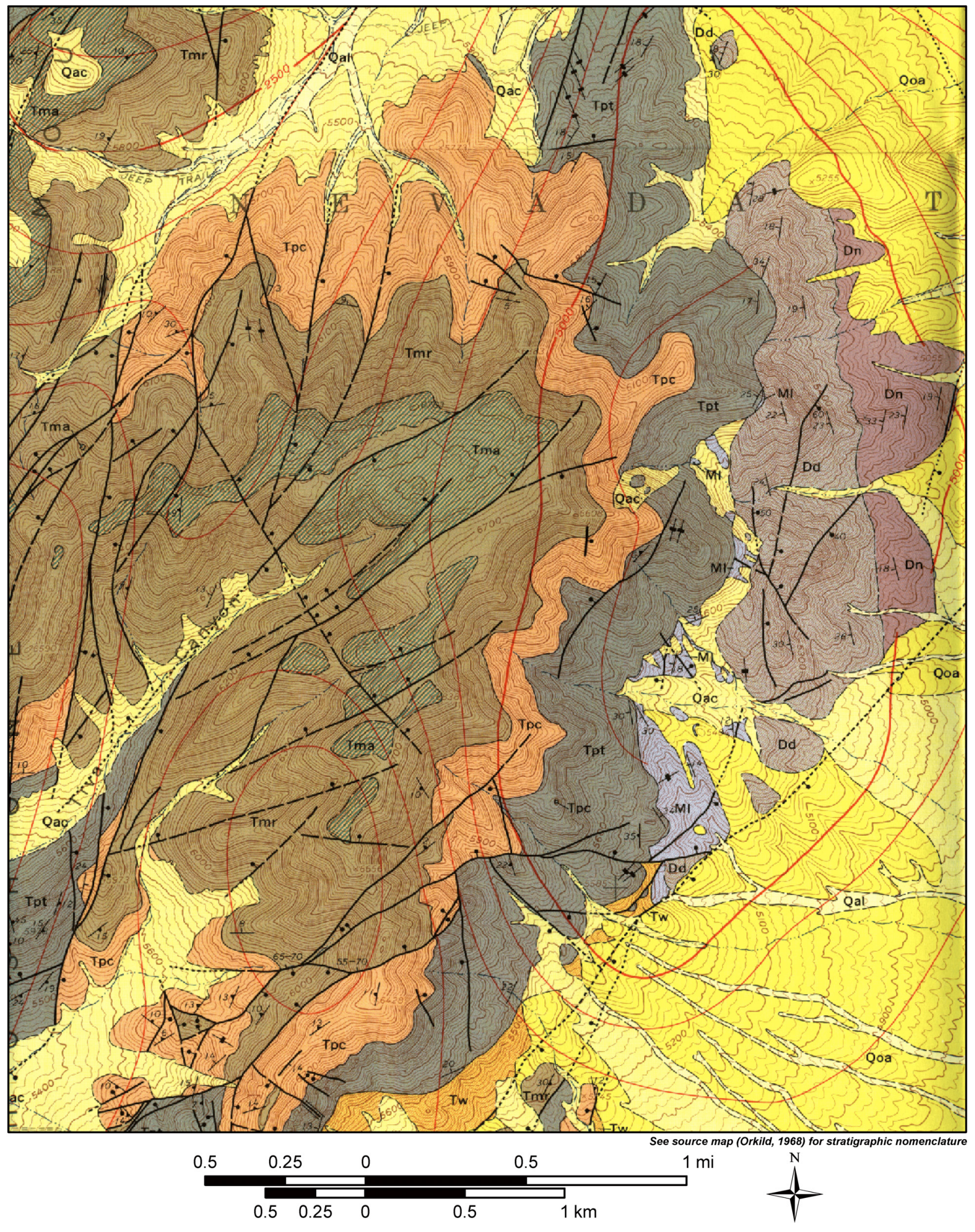

Figure 3-1

Geologic Map of the Shoshone Mountain Area

(from Orkild, 1968) 


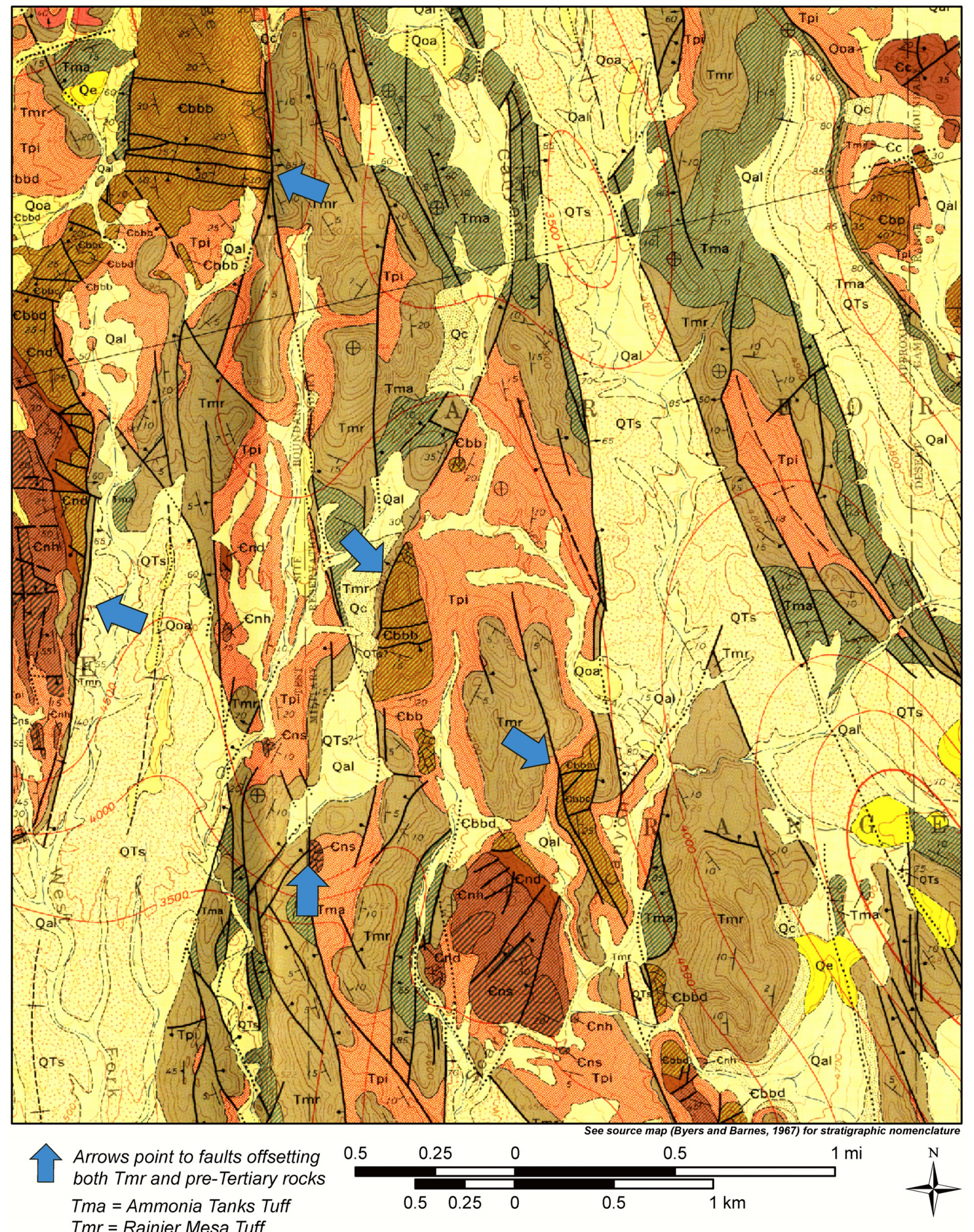

Figure 3-2

Geologic Map of the Halfpint Range Area

(from Byers and Barnes, 1967) 


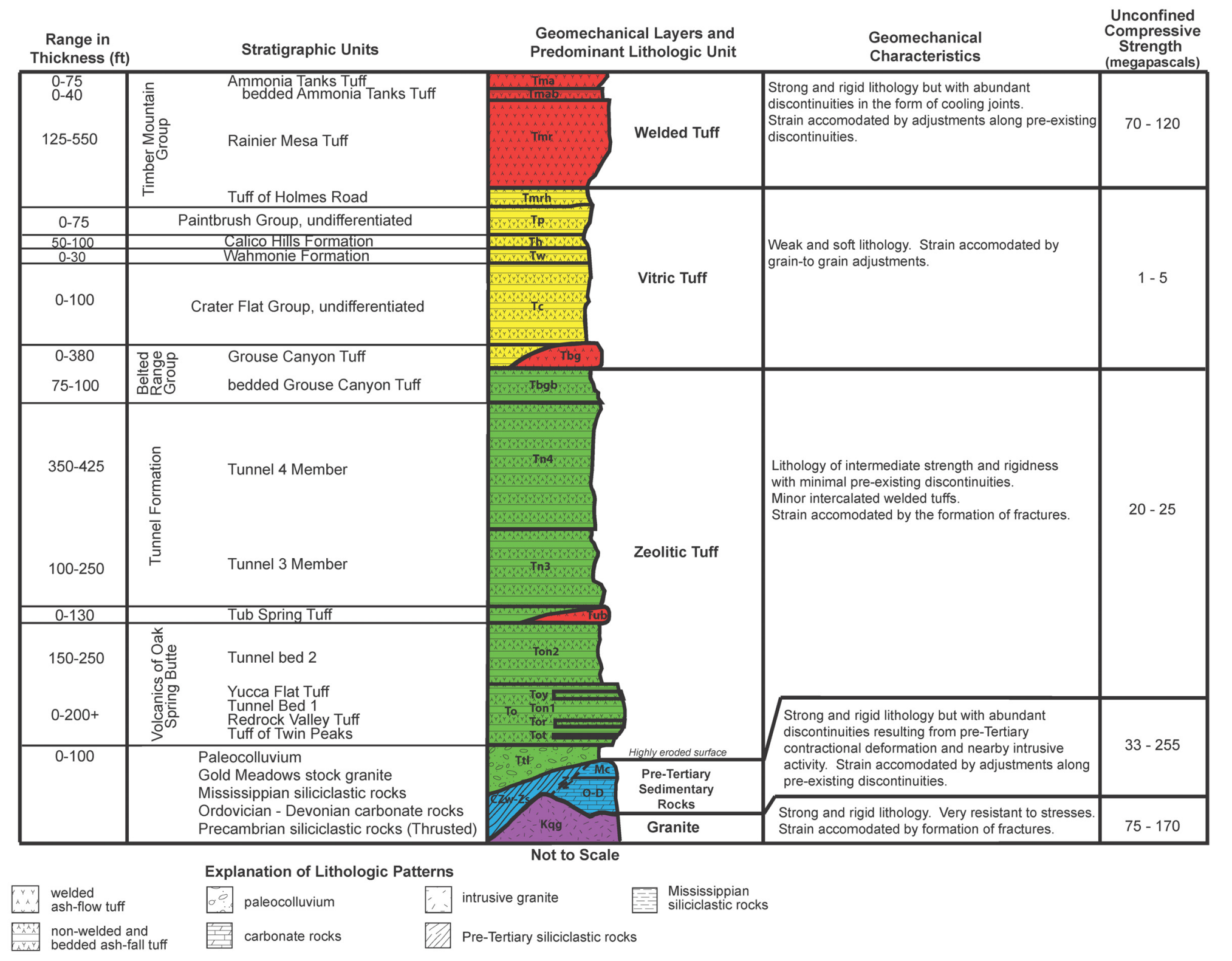

Figure 3-3

Schematic Stratigraphic and Geomechanical Column for Rainier and Aqueduct Mesas 


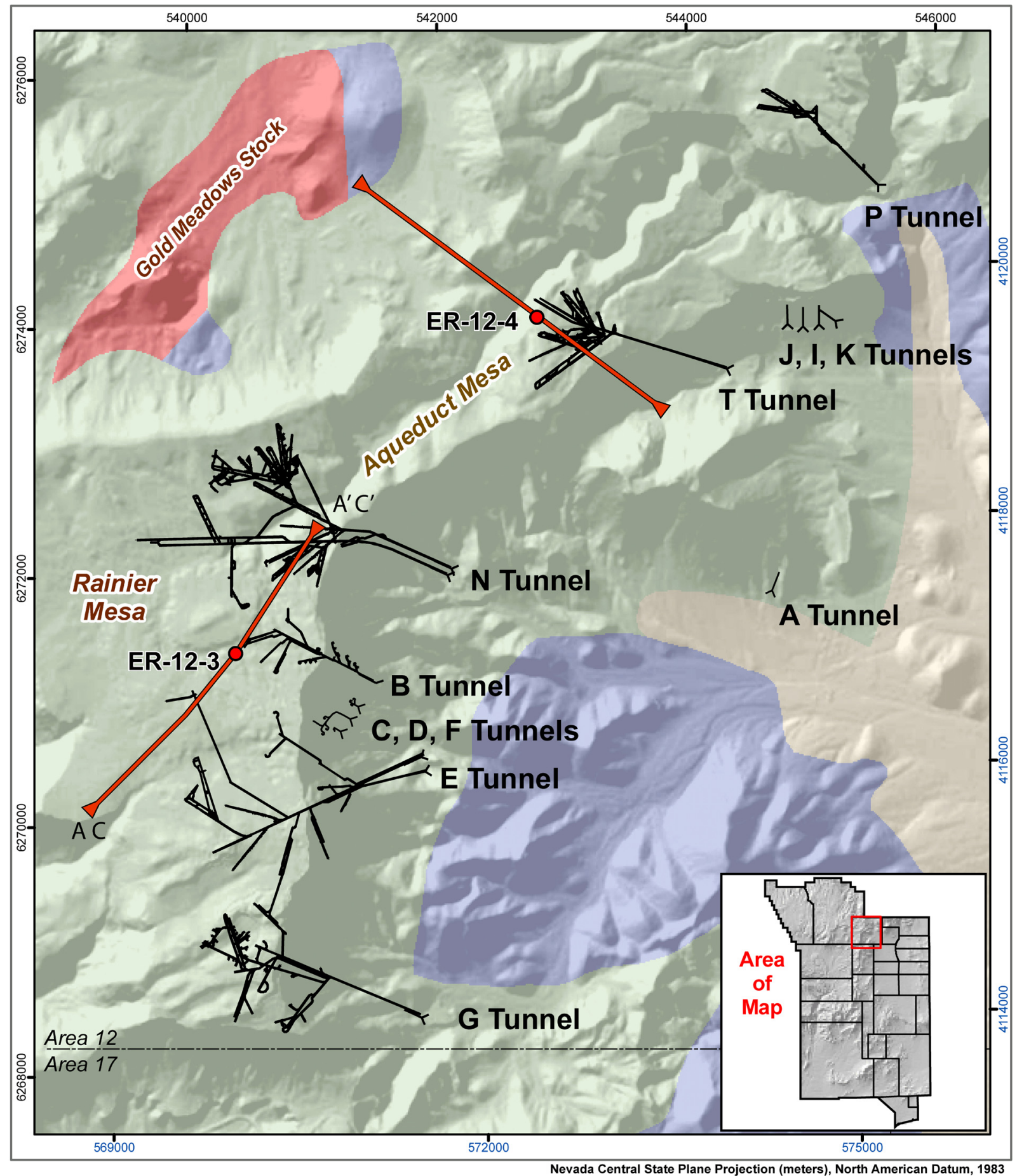

Quaternary/Tertiary alluvial sediments

Tertiary volcanic rocks

Mesozoic granitic rocks

Paleozoic \& Precambrian sedimentary rocks

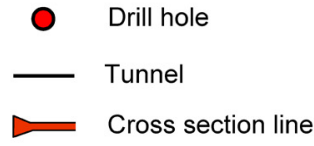

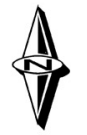

$\begin{array}{lll}0.5 & 0.25 \quad 0\end{array}$

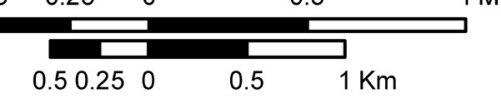

Black tick marks are in Nevada State Plane, Central Zone, NAD83, meters Blue tick marks are in Universal Transverse Mercator, NAD83, meters

Geology from Nevada Bureau of Mines \& Geology (1996)

Figure 3-4

Generalized Geologic Map of the Rainier Mesa Area Showing Locations of Tunnel Complexes 


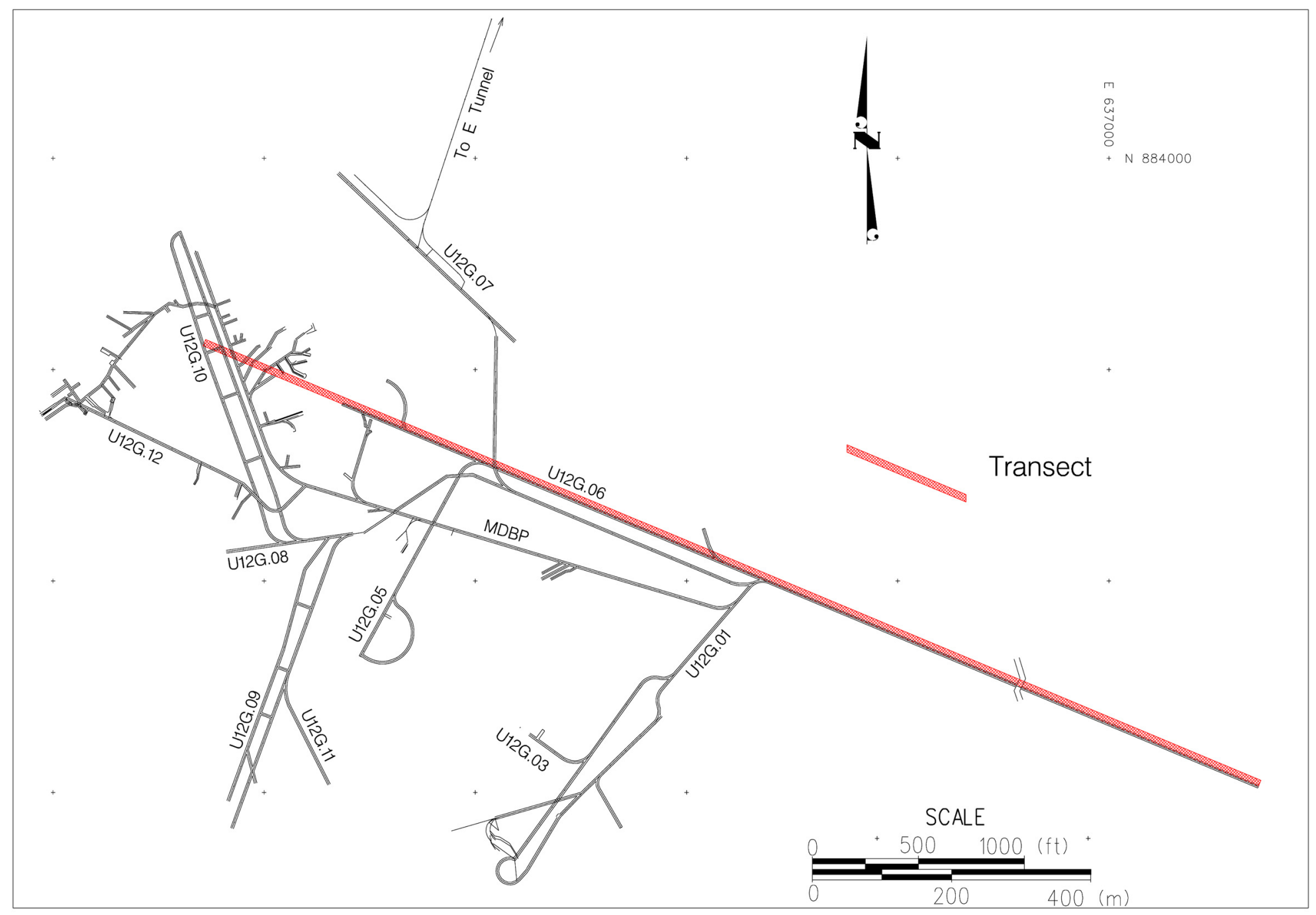

Figure 3-5

Reference Map for U12g Tunnel Showing Locations of Mined Drifts and Transect Line 


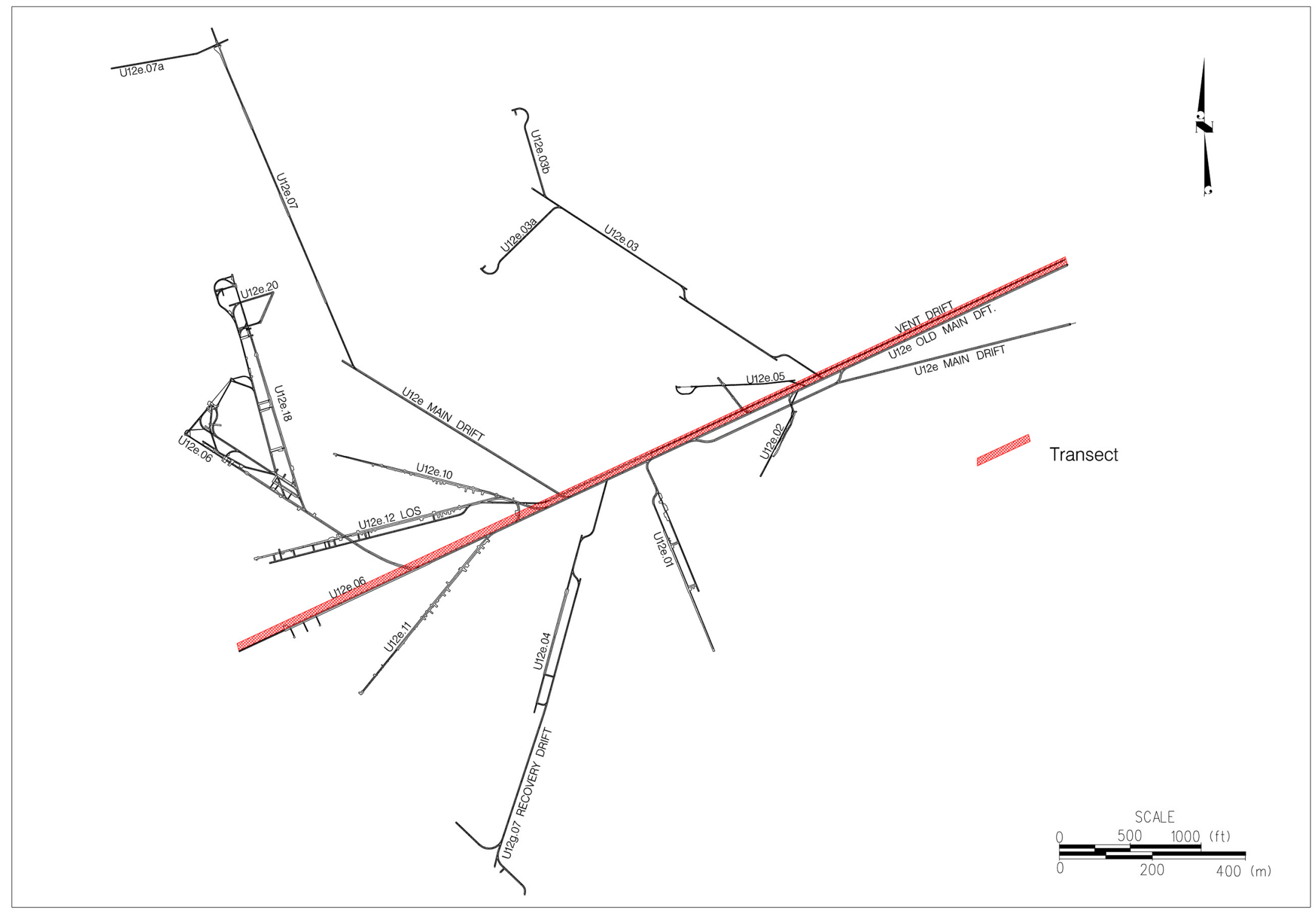

Figure 3-6

Reference Map for U12e Tunnel Showing Locations of Mined Drifts and Transect Line 


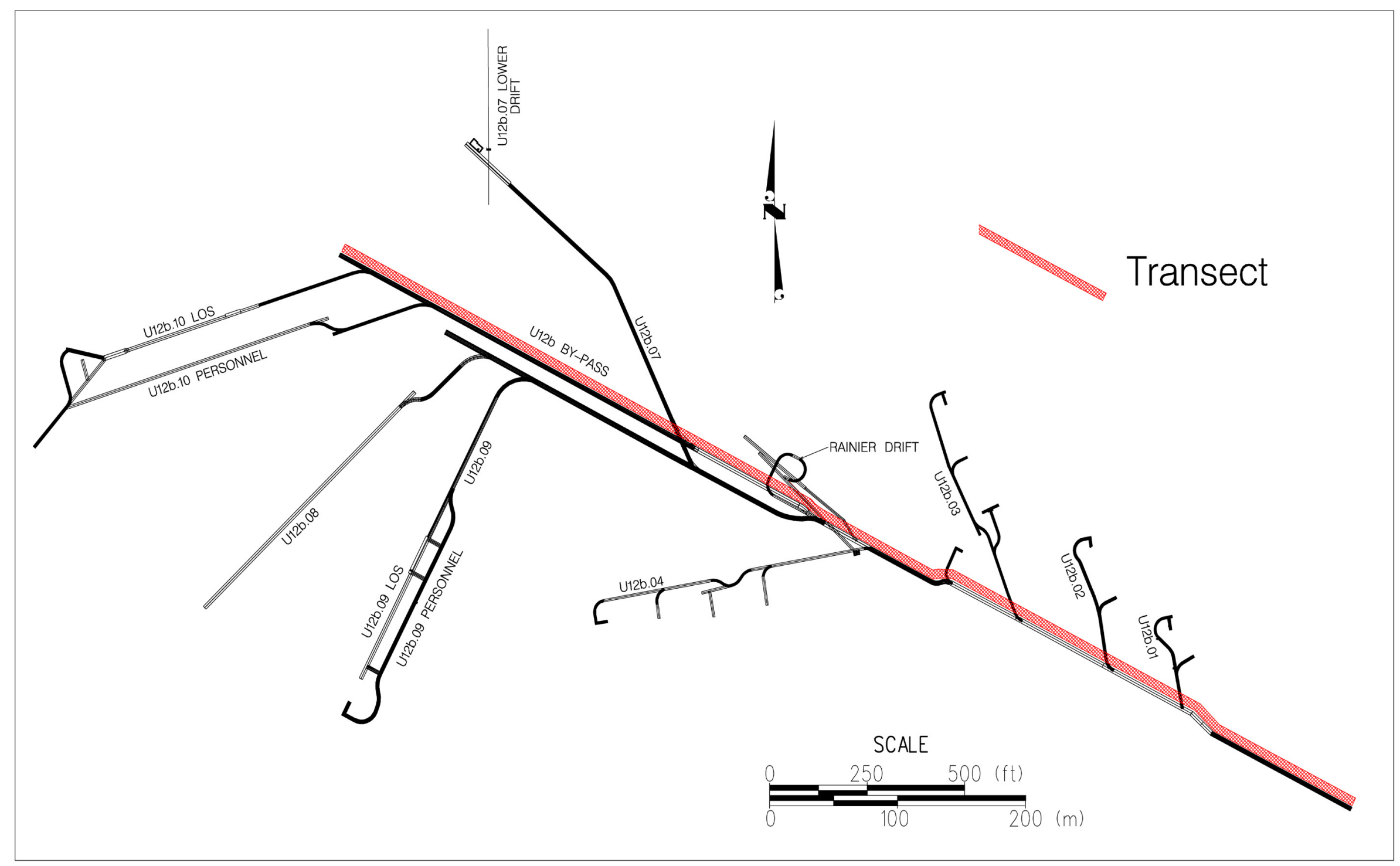

Figure 3-7

Reference Map for U12b Tunnel Showing Locations of Mined Drifts and Transect Line 


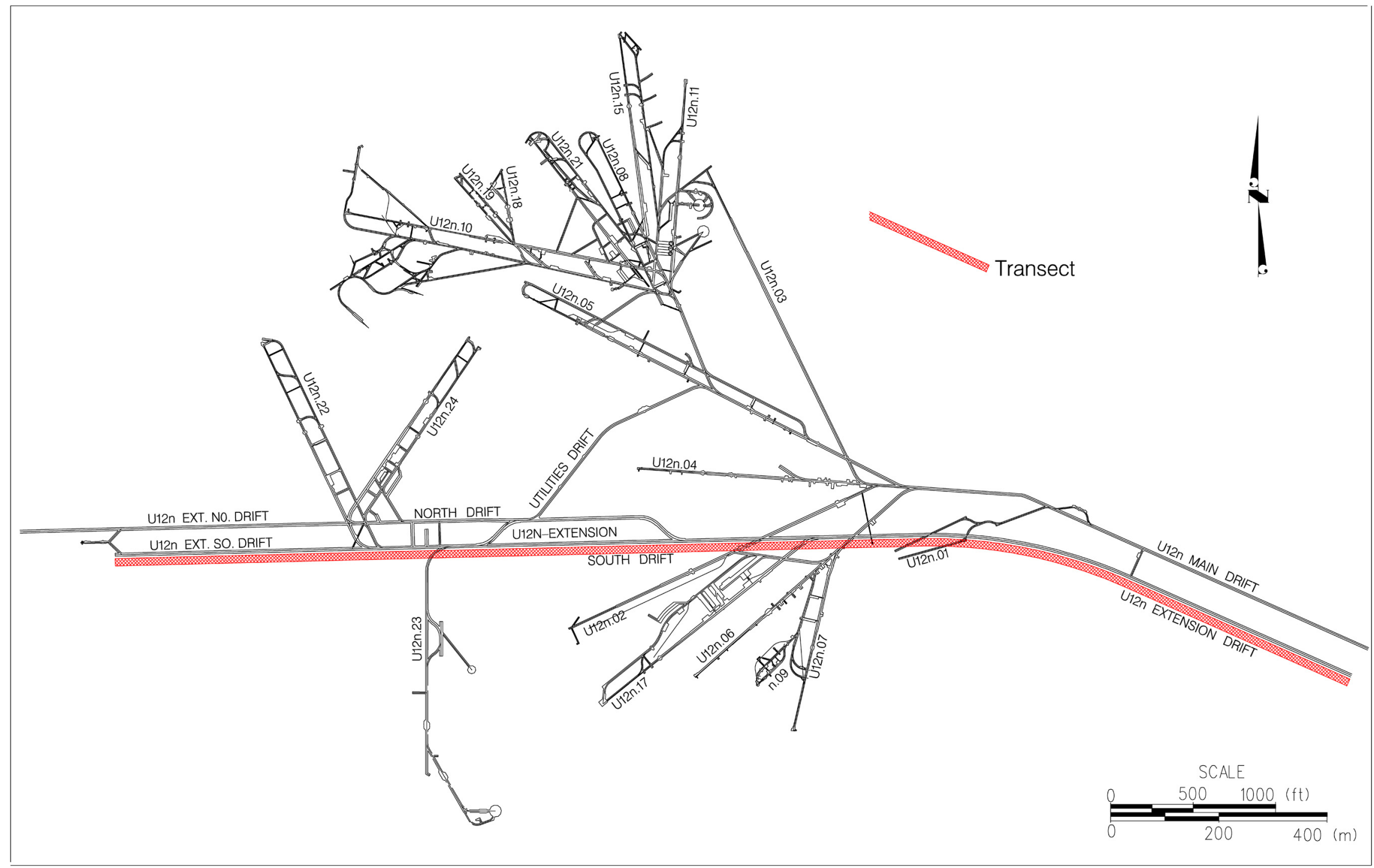

Figure 3-8

Reference Map for U12n Tunnel Showing Locations of Mined Drifts and Transect Line 


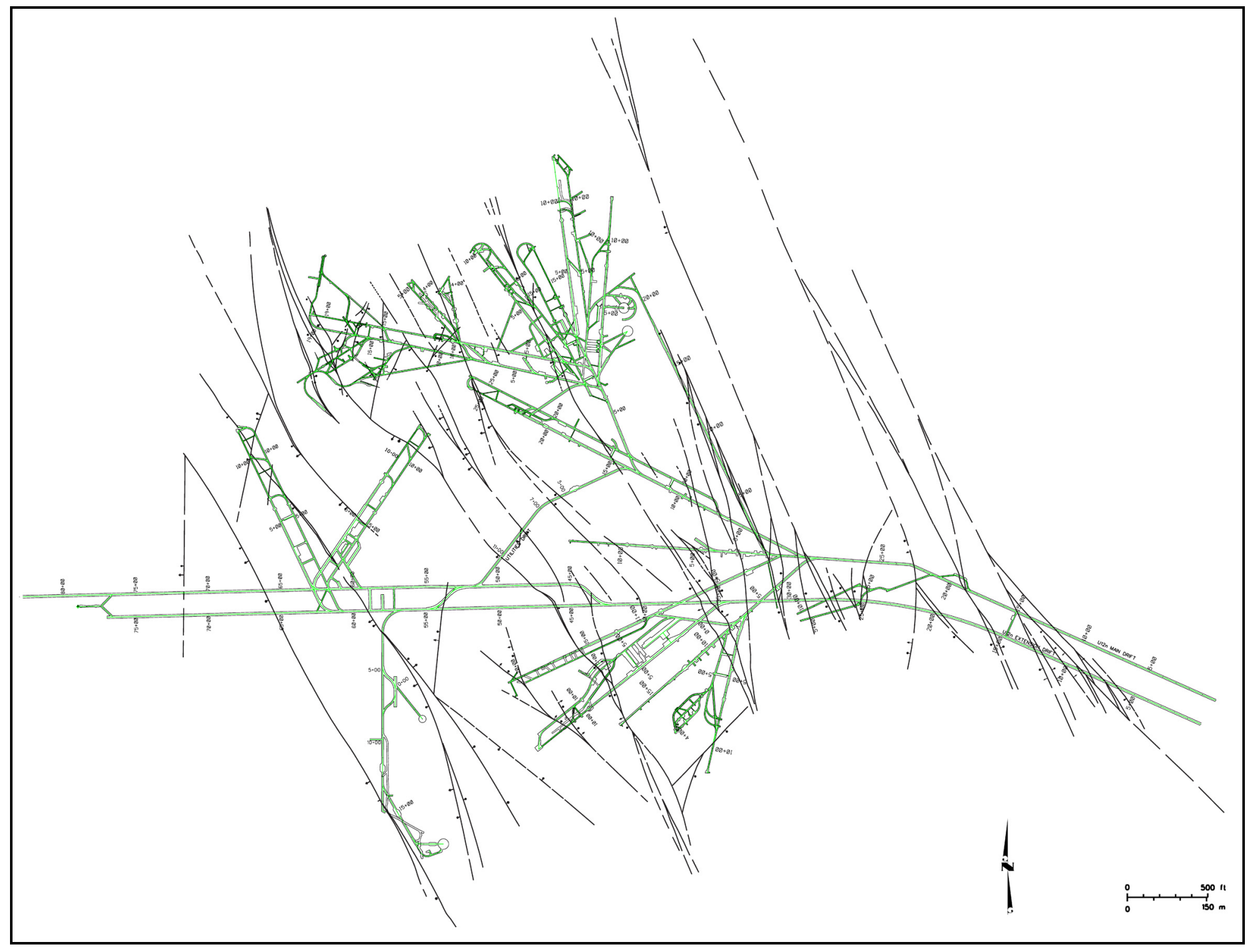

Figure 3-9

Simplified Map of U12n Tunnel Showing Drifts (green) and Fault Traces (black) 


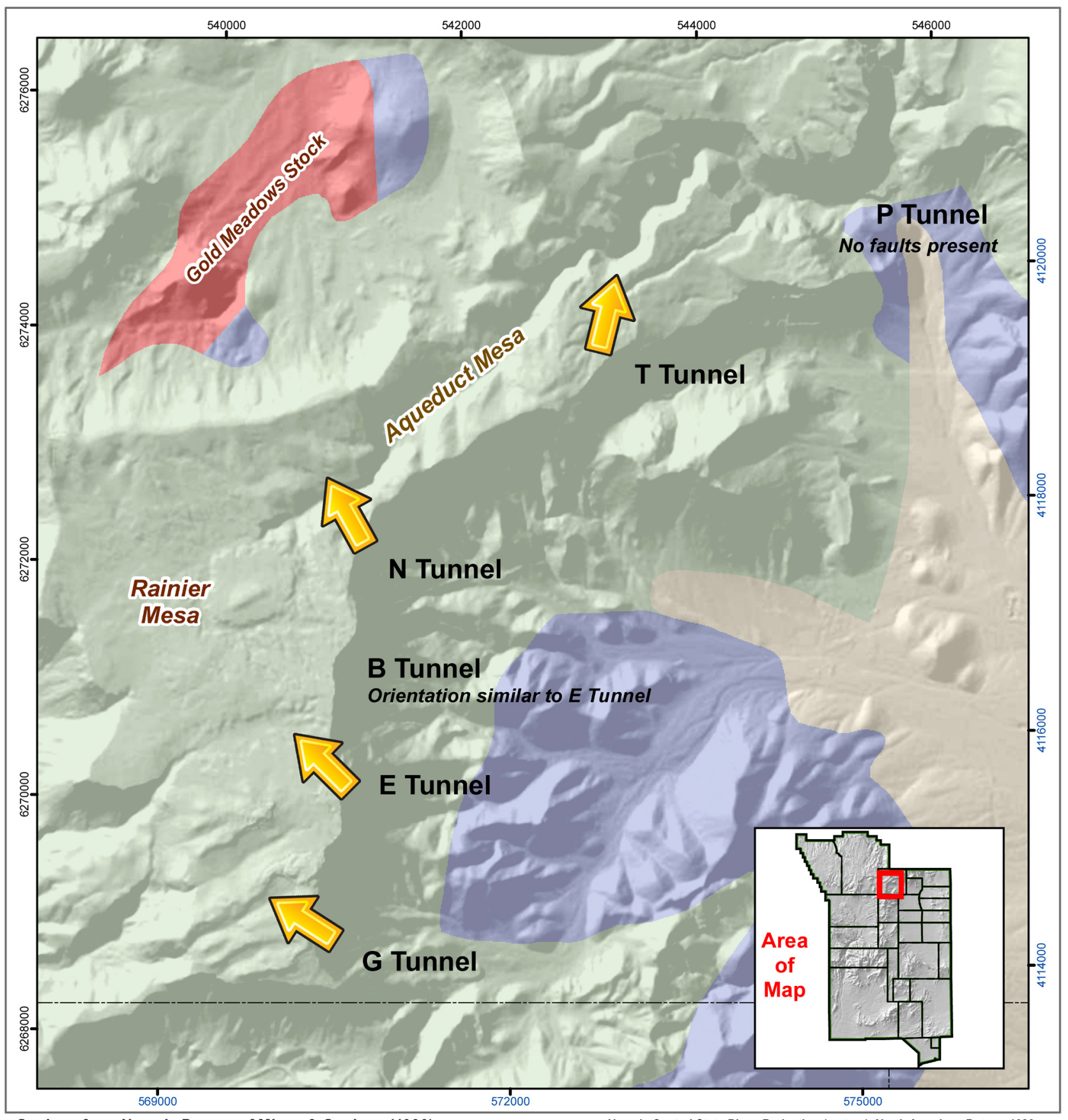

Geology from Nevada Bureau of Mines \& Geology (1996)

Nevada Central State Plane Projection (meters), North American Datum, 1983

Quaternary/Tertiary alluvial sediments

Tertiary volcanic rocks

Mesozoic granitic rocks

Paleozoic \& Precambrian sedimentary rocks

NNSS operational area

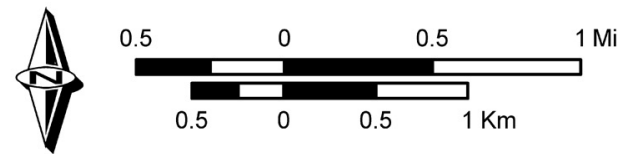

Black tick marks are in Nevada State Plane, Central Zone, NAD83, meters Blue tick marks are in Universal Transverse Mercator, NAD83, meters

Figure 3-10

Generalized Geologic Map of the Rainier Mesa Area Showing Average Strikes of Faults (relative to north) in Tunnel Complexes 


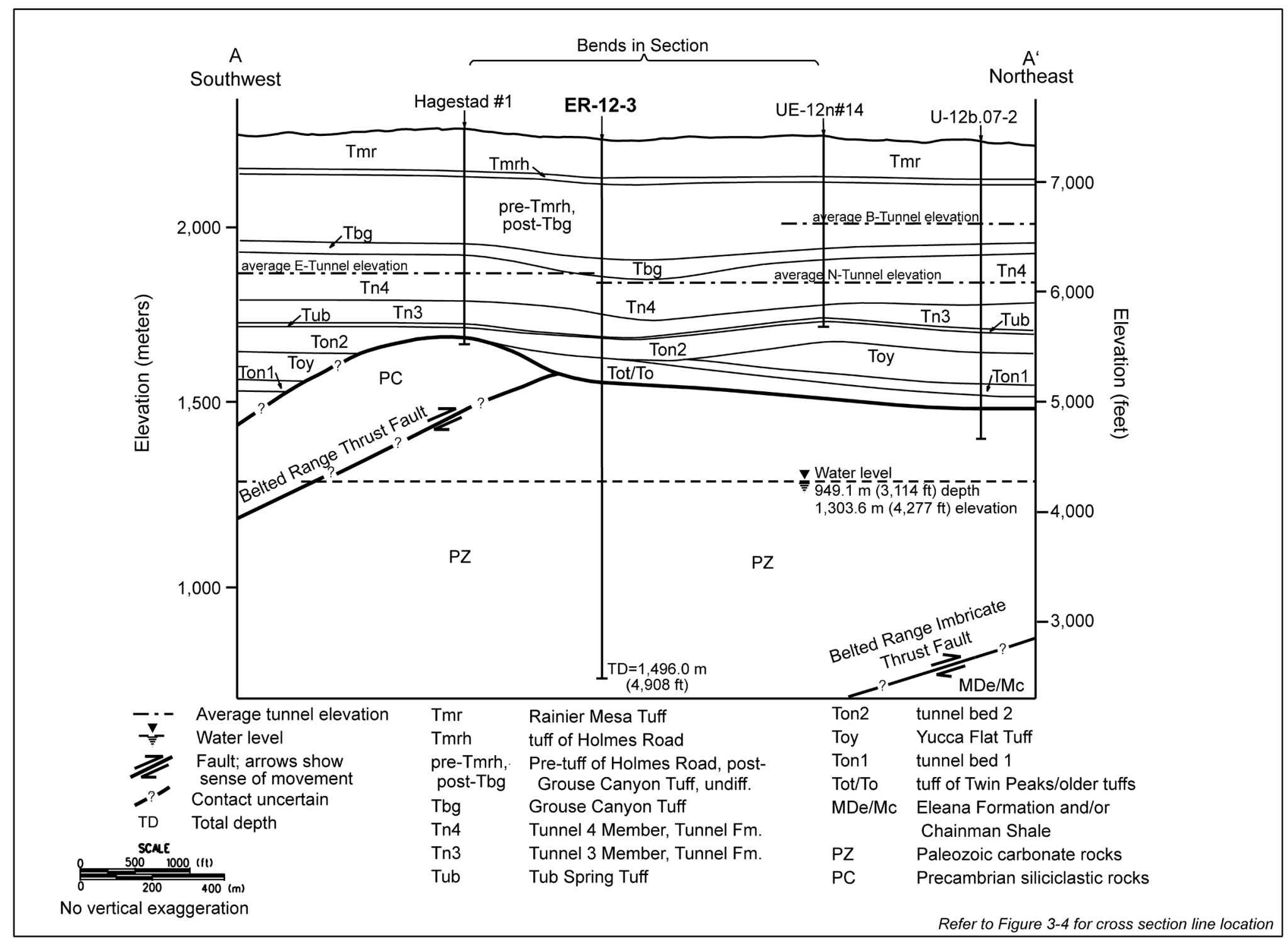

Figure 3-11

Southwest-Northeast Geologic Cross Section A-A' through Well ER-12-3 Showing Geologic Setting near U12e, U12b, and U12n Tunnels (from NNSA/NSO, 2006a) 


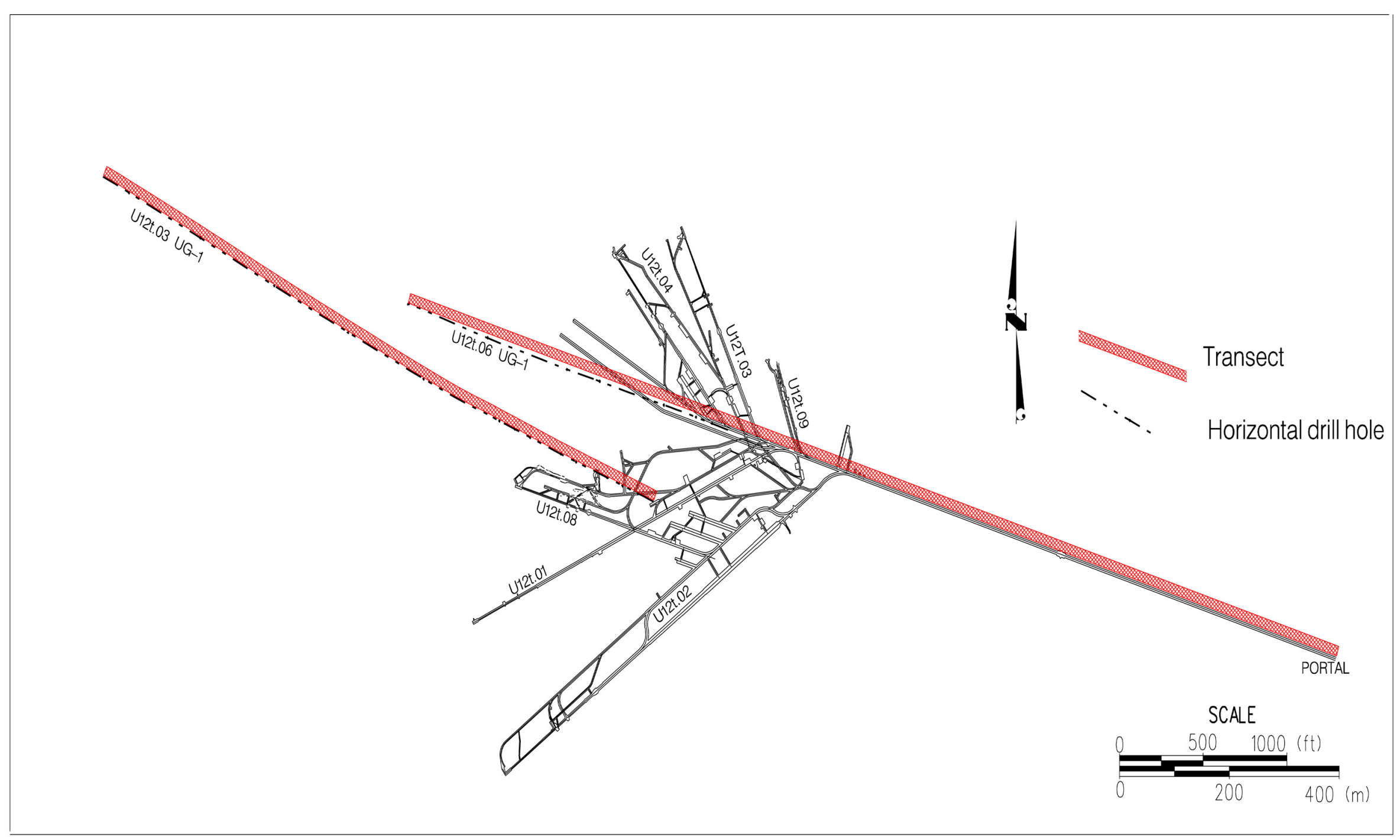

Figure 3-12

Reference Map for U12t Tunnel Showing Locations of Mined Drifts and Transect Lines 


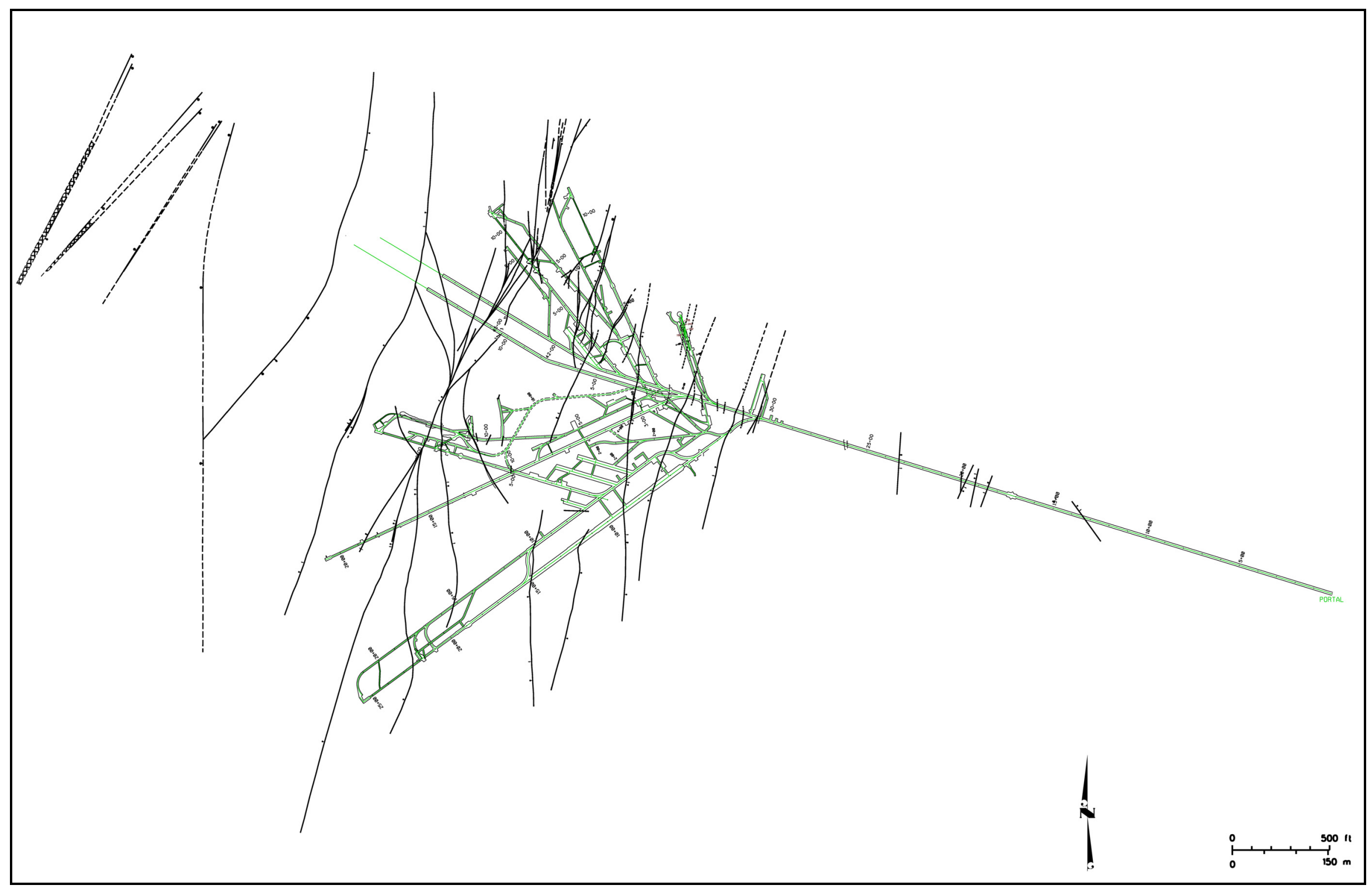

Figure 3-13

Simplified Map of U12t Tunnel Showing Drifts (green) and Fault Traces (black) 


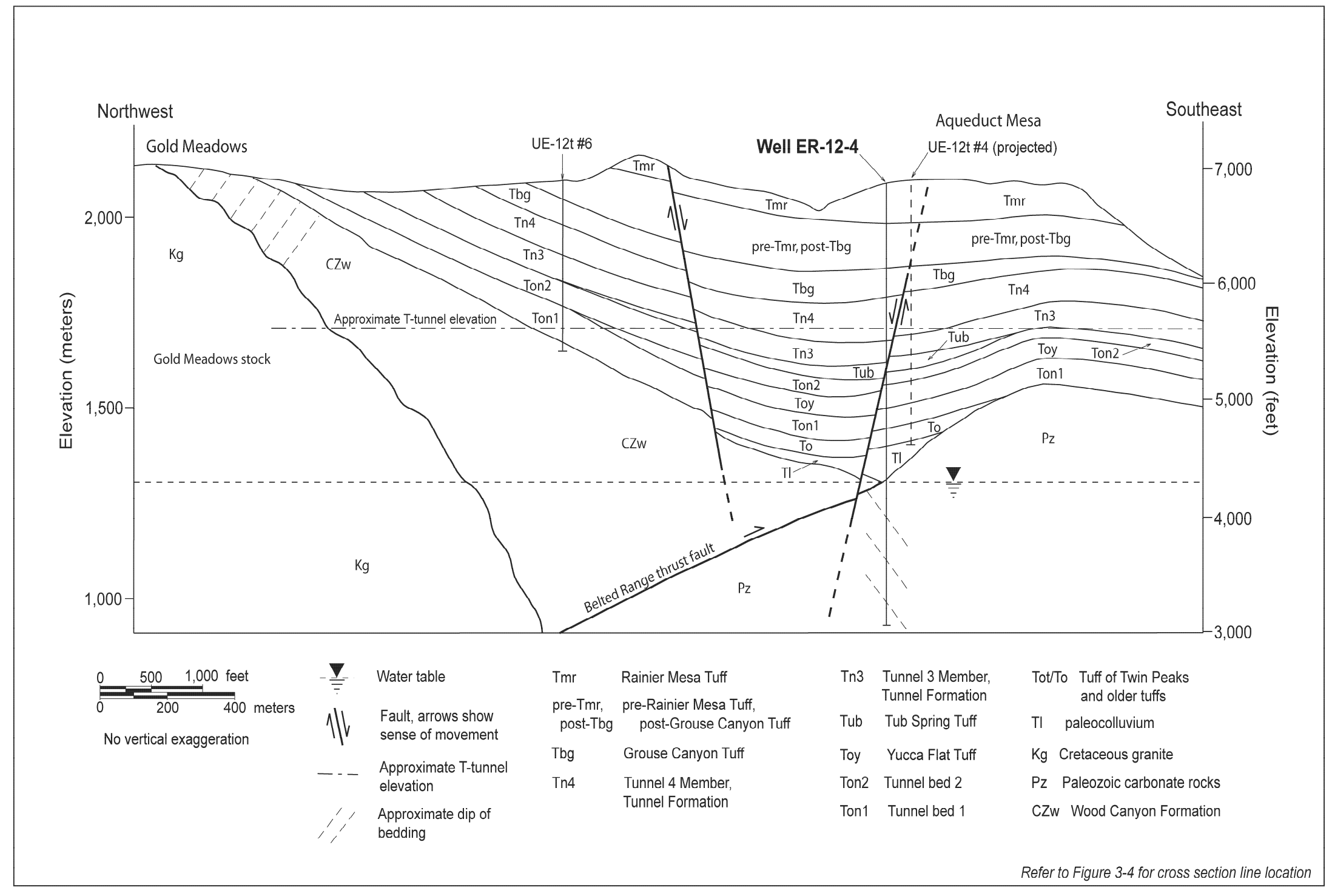

Figure 3-14

Northwest-Southeast Geologic Cross Section through Well ER-12-4 Showing Geologic Setting near U12t Tunnel (from NNSA/NSO, 2006b) 


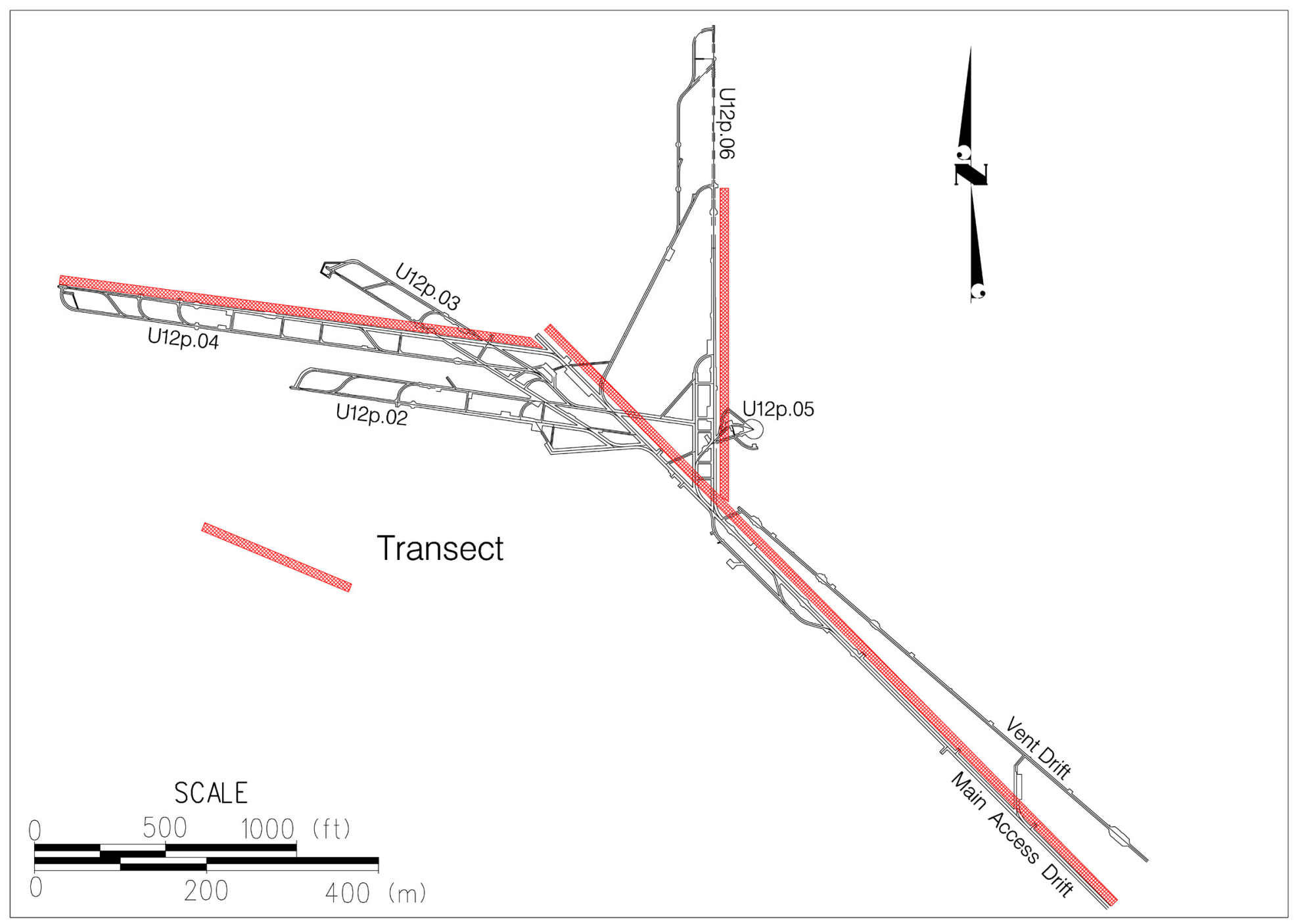

Figure 3-15

Reference Map for U12p Tunnel Showing Locations of Mined Drifts and Transect Lines 
This page intentionally left blank. 


\subsection{Conclusions Concerning Fault Abundances and Extents}

The data presented here lead to some conclusions concerning the abundance of faults in Rainier Mesa and their vertical and lateral extents.

\subsection{Abundance of Faults at Rainier Mesa}

- No faults that offset the welded-tuff caprock have been mapped at the surface of Rainier Mesa and only a few such faults are mapped at the surface of Aqueduct Mesa (Gibbons, et al., 1963; Sargent and Orkild, 1973; Figure 2-2).

- Geologists looked intensely for faults during the WTP. (Faults are believed to be detrimental to the containment of underground nuclear explosions, and can serve as pathways for contaminants in the near-field immediately after an UGT.) Our more recent examination of the mesa surface and edges for the WTP has validated the original mapping conducted in the 1960s: no additional faults were discovered.

- Only small (typically <3 m [10 ft] displacement) faults have been located by mapping over 77.2 kilometers (48 miles) of mined tunnels under Rainier Mesa. Again, these drifts were scrutinized closely for structures during the WTP. It is noteworthy that typical faults elsewhere in the RM-SM CAU model and those included in the other UGTA CAU models generally have $>60 \mathrm{~m}$ (200 ft) of displacement. However, it should be noted that a few largedisplacement faults have been mapped at RM, and these are included in the RM-SM CAU hydrostratigraphic framework model (Table 4-1; NSTec, 2007).

- The character of faults in Rainier Mesa tunnels (i.e., small displacement, minimal damage zones, etc.) does not seem to indicate large-scale movement such as those associated with B\&R extension in adjacent areas. Examples of typical faults encountered in the tunnel complexes of Rainier Mesa are shown in Figures 4-1, 4-2, and 4-3 (Prothro et al., 2009).

\subsection{Height of Faults}

- Field mapping along the mesa edge reveals few faults in the vitric bedded tuffs. These units include “Tigl” and "Tps” of Gibbons et al., (1963) (Figure 2-2), which are equivalent to the UGTA hydrostratigraphic unit (HSU) Timber Mountain lower vitric-tuff aquifer (TM-LVTA) (Figure 4-4). There are, however, some faults mapped in the underlying zeolitic units, e.g., “Tilt1” through "Tilt 4" of Gibbons et al. (1963), which are equivalent to the UGTA HSUs lower tuff confining unit (LTCU) and Oak Spring Butte confining unit (OSBCU). 
Table 4-1

Faults in the Rainier Mesa-Aqueduct Mesa Area That Are Included in the Rainier Mesa-Shoshone Mountain Hydrostratigraphic Framework Model

\begin{tabular}{|l|c|c|c|l|}
\hline Fault Name & $\begin{array}{c}\text { Approximate } \\
\text { Strike }\end{array}$ & $\begin{array}{c}\text { Dip } \\
\text { Magnitude } \\
\text { and } \\
\text { Direction }\end{array}$ & $\begin{array}{c}\text { Approximate } \\
\text { Offset } \\
\text { meters } \\
\text { (feet) }\end{array}$ & \multicolumn{1}{|l|}{ Crosscutting Relationships } \\
\hline $\begin{array}{l}\text { Northwest } \\
\text { T-Tunnel Fault }\end{array}$ & $\mathrm{NE}$ & $75^{\circ} \mathrm{SE}$ & $\begin{array}{c}30 \\
(100)\end{array}$ & N/A \\
\hline RM1 & $\mathrm{NW}$ & $75 \mathrm{SE}$ & $\begin{array}{c}38 \\
(125)\end{array}$ & N/A \\
\hline RM3 & $\mathrm{N}-\mathrm{NE}$ & $75^{\circ} \mathrm{SE}$ & $\begin{array}{c}91 \\
(300)\end{array}$ & N/A \\
\hline RM4 & $\mathrm{NE}$ & $85^{\circ} \mathrm{NW}$ & $\begin{array}{c}91 \\
(300)\end{array}$ & N/A \\
\hline RM5 & $\mathrm{N}$ & $70^{\circ} \mathrm{NW}$ & $\begin{array}{c}21 \\
(70)\end{array}$ & $\begin{array}{l}\text { Cuts Well ER-12-4. Faults out welded } \\
\text { Tub Spring Tuff. Terminates at depth } \\
\text { against east-dipping fault(s). }\end{array}$ \\
\hline $\begin{array}{l}\text { T-Tunnel Main } \\
\text { Drift Fault }\end{array}$ & & $\begin{array}{c}30-61 \\
(100-200)\end{array}$ & N/A \\
\hline
\end{tabular}

Source: NSTec, 2007

- Faulting observed in the tunnels appears similar in spacing and character to faults mapped in tuff beds exposed around RM. Most of these surface faults appear to be restricted to the zeolitized tuffs, though a few have been mapped up through to the caprock at Aqueduct Mesa.

- Faults are unlikely to propagate through the less indurated, unaltered ash-fall tuff units between the welded caprock (Tmr) and the zeolitic tuffs (generally Tunnel beds). Stress in the more friable, weaker deposits would dissipate or be taken up by grain-to-grain movement. Such movement would be manifested as deformation bands rather than discrete fault planes. In tunnels that penetrate above the upper level of zeolitization, many fewer faults were observed than in the zeolitized tuffs.

- The main lithologic units of the mesa can be subdivided on the basis of geomechanical characteristics that might control their propensity to propagate faults. As illustrated in Figure 3-3, the welded tuff caprock, the vitric tuff section, the zeolitized tuffs, and the various pre-Tertiary rocks differ greatly in their strength and related characteristics.

\subsection{Lower Extent of Faults}

We believe that most of the smaller faults in RM do not penetrate below the base of the Tertiaryage volcanic section. Very few surface faults in the zeolitized bedded tuff section are shown to extend into pre-Tertiary.

- Increasing displacement with depth along individual faults ("growth faulting") is not observed, so it is less likely such small magnitude faults (as mapped at tunnel level) extend vertically up or down very far. 
- Nearly all of the faults mapped at tunnel level in RM dip steeply to the west. This would seem to imply that they may not converge at depth, though some of the faults that dip the opposite direction may terminate against dominant west-dipping faults in an antithetic relationship.

- The paleocolluvium ("Tlc," or argillic-tuff confining unit [ATCU]) deposited at the base of the Tertiary section is a horizon with hard pre-Tertiary (dolomite or granite) blocks in a clayrich, fine-grained matrix. Its low strength is not likely to support fractures or faults, particularly open pathways. Few fractures are seen in outcrops of paleocolluvium elsewhere.

- The contrast in physical properties between the volcanic units and the underlying Paleozoic rocks is significant and units of different properties likely accommodate stresses in different ways.

- The volcanic units were deposited on a surface with significant relief. The syncline noted in the volcanic units is roughly parallel to the Belted Range thrust (BRT) fault (Figure 3-14), and some geologists have proposed that this synclinal feature may be a strike valley. It is reasonable to expect that some settling/adjustments have occurred within the tuffs overlying this irregular surface that may now be manifested as small adjustment faults.

- Fault frequency and orientation in pre-Tertiary rocks in the RM area are generally different than those in the volcanic rocks and few faults are observed to offset both units.

\subsection{Fault Length}

As mentioned above, the fault traces depicted on the WTP tunnel maps reflect the conservative philosophy of the WTP. There was a tendency to connect individual fault intercepts mapped in the various drifts and core holes to form a single fault trace. This has likely yielded fault traces longer than would be predicted by models based strictly on rock mechanics. Since fault height and depth and amount of offset are related to length, the rock mechanics method would require displacements greater than those observed, based on the conservative practice to connect similarly oriented fault segments. However, there are cases where a fault is shown as terminated arbitrarily at the edge of the map area.

Scholz (2005) presents a relationship between fault displacement and length in a variety of lithologies. In the RM tunnels, fault dips and displacements are quite variable within short distances, and their lengths are not bounded well enough to determine if they follow the scaling algorithm of Scholz (2005). A close examination of the tunnel-level maps of N- and T-Tunnels did not produce any examples of faults with unequivocal termination points. In several cases, however, faults of low displacement $(<2 \mathrm{~m}$ ) are shown (as a result of conservatively connecting faults in different drifts) to extend far longer than the approximately $200 \mathrm{~m}$ predicted by Scholz (2005). 
This page intentionally left blank. 


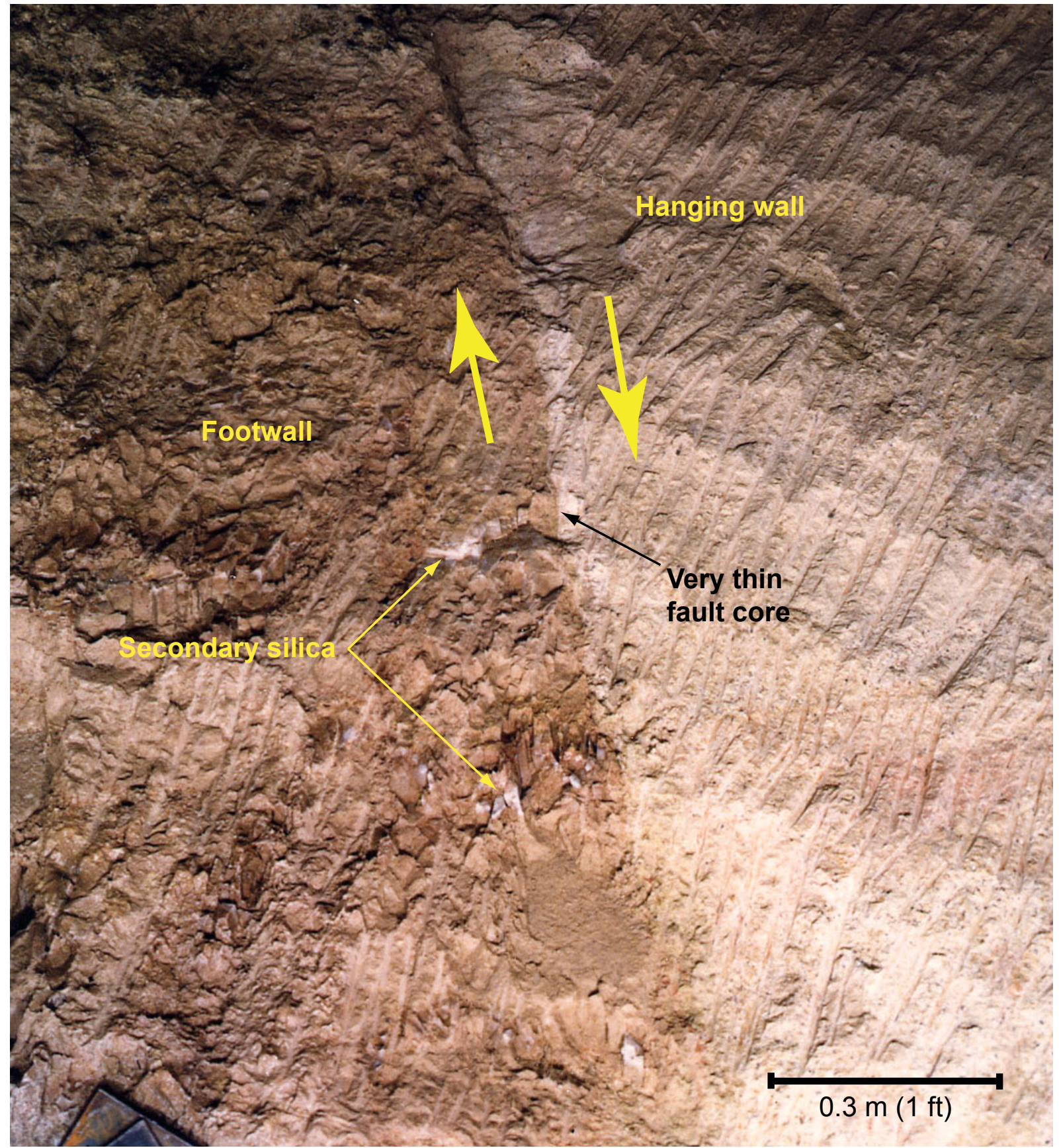

This normal fault is within tuff confining unit in N-Tunnel. The fault has a very thin fault core only a few millimeters wide. No damage is visible in the hanging wall. The footwall has a shattered appearance and secondary silica is present in a few places. Diagonal striations are tooth marks from the mining machine.

Figure 4-1

Fault Station N-21BP-1

(U12n Tunnel) 


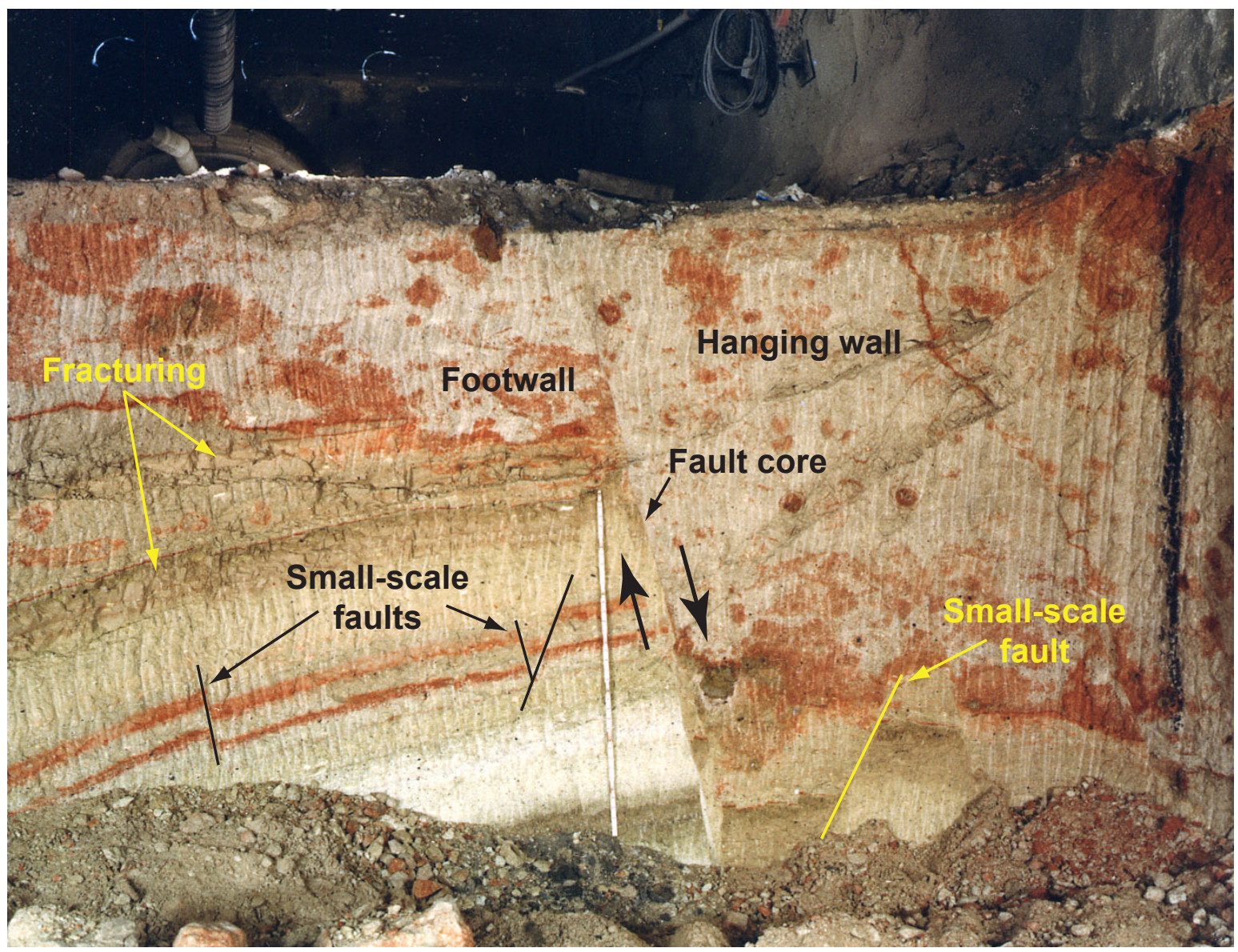

This normal fault within tuff confining unit in N-Tunnel shows minor damage consisting of fracturing and small-scale faulting. Fracturing is most pronounced in silicified beds in the footwall. The fault core is very narrow, generally less than

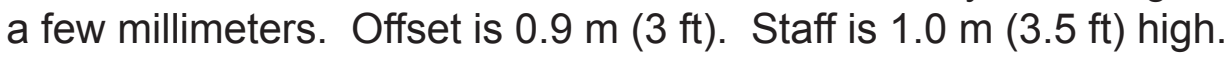

Figure 4-2

Fault Station N-21LOS-1

(U12n Tunnel) 


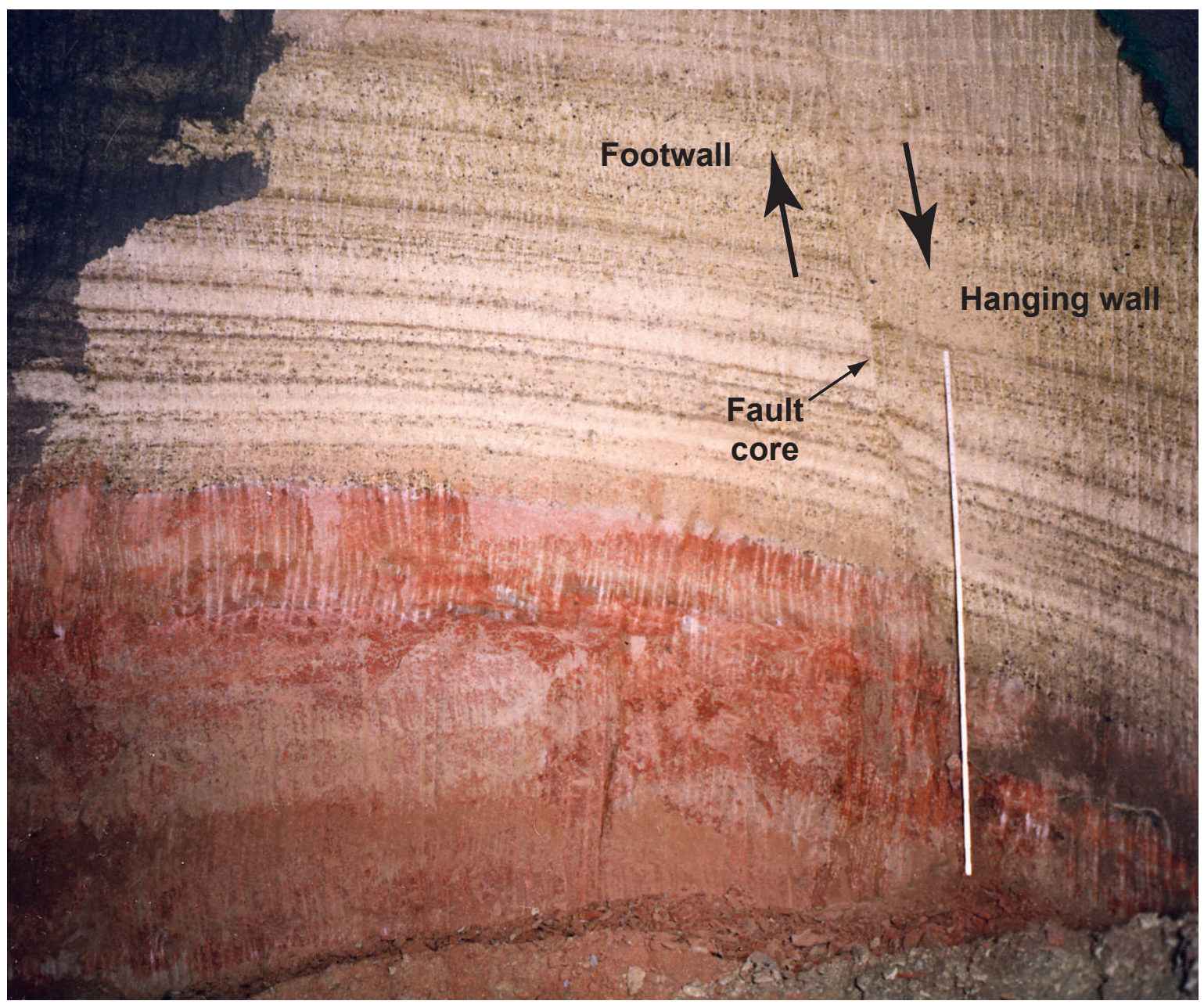

This normal fault within tuff confining unit in N-Tunnel shows no fault-related damage. The width of the fault core is less than $1 \mathrm{~cm}(0.4 \mathrm{in})$. Offset is $0.3 \mathrm{~m}(1 \mathrm{ft})$. Staff is $1.8 \mathrm{~m}(6 \mathrm{ft})$ high.

Figure 4-3

Fault Station N-21LOS-2

(U12n Tunnel) 


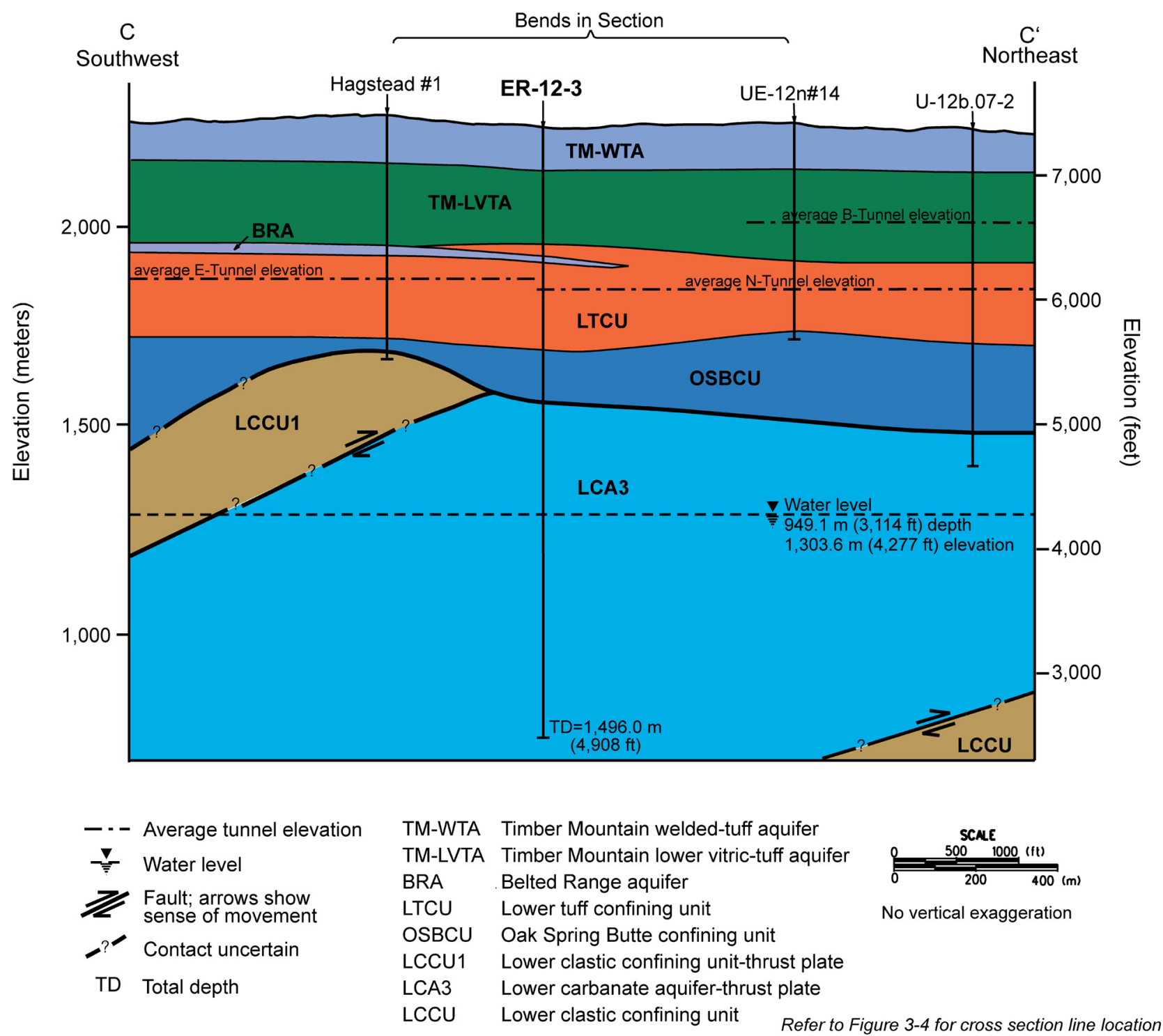

Figure 4-4

Southwest-Northeast Hydrogeologic Cross Section C-C' through Well ER-12-3 


\subsection{Causes of Faulting at Rainier Mesa}

Evaluation of the observations described above may lead to a hypothesis for the cause of most faulting in Rainier Mesa. This may in turn provide a means of predicting fault properties and extents for use in the sub-CAU models.

The Rainier Mesa area was minimally extended during syn- and post-volcanic B\&R extension. The high volcanic plateau with nearly flat-lying caprock and scarcity of faults reflect this relatively stable history. The faults mapped in RM tunnels have relatively small displacements and may not necessarily be related to $B \& R$ extension. Rather, the small faults may be related to adjustment of planar volcanic units draped over paleotopography developed on the eroded preTertiary rocks.

The rocks in the RM area, including the volcanic units, were probably subjected to stresses related to significant nearby structural events such as the opening of the Yucca Flat basin to the east and development of the calderas to the west. The Silent Canyon caldera complex was formed about $13 \mathrm{Ma}$ and would have caused a seismic disturbance that shook the Grouse Canyon and older tuffs. Formation of the Timber Mountain caldera at about 11.5 Ma would have shaken even younger units. 
This page intentionally left blank. 


\subsection{Summary and Conclusions}

The geologic setting and history, along with observations through 50 years of detailed geologic field work, show that large-displacement (i.e., >30 m [100 ft]) syn- to post-volcanic faults are rare in the Rainier Mesa area. Faults observed in tunnels and drill holes are mostly tight, with small and variable displacements (most less than $1.5 \mathrm{~m}[5 \mathrm{ft}]$ ) and small associated damage zones. Faults are much more abundant in the zeolitized tuffs than in the overlying vitric tuffs, and there is little evidence that faults extend from the tuff section through the argillic paleocolluvium into pre-Tertiary rocks. The differences in geomechanical characteristics of the various tuff lithologies of RM suggest that most faults on RM are limited to the zeolitic units sandwiched between the overlying vitric bedded tuffs (TMLVTA) and the underlying Paleozoic units (LCA3 and LCCU1). 
This page intentionally left blank. 


\subsection{References Cited}

Bechtel Nevada, 2006. A Hydrostratigraphic Model and Alternatives for the Groundwater Flow and Contaminant Transport Model of Corrective Action Unit 97: Yucca Flat-Climax Mine, Lincoln and Nye Counties, Nevada. DOE/NV/11718--1119. Las Vegas, NV.

BN, see Bechtel Nevada.

Byers, F. M., Jr. and H. Barnes, 1967. "Geologic Map of the Paiute Ridge Quadrangle, Nye and Lincoln Counties, Nevada.” U.S. Geological Survey Geologic Quadrangle Map GQ-577, scale 1:24,000. Washington, DC.

Cole, J. C., and P. H. Cashman, 1999. Structural Relationships of Pre-Tertiary Rocks in the Nevada Test Site Region, Southern Nevada. U.S. Geological Survey Professional Paper 1607.

DOE, see U.S. Department of Energy, National Nuclear Security Administration Nevada Site Office.

Drellack, S. L., Jr., L. B. Prothro, J. L. Gonzales, J. M. Mercadante, and D. N. Haugstad, 2008. Written Communication, Subject: "Low Water Production from Carbonate Aquifers at Rainier Mesa: Implications for the Distribution of Hydraulic Conductivity within the Lower Carbonate Aquifer, Nevada Test Site and Vicinity.” Preliminary report prepared for the U.S. Department of Energy, National Nuclear Security Administration Nevada Site Office by National Security Technologies, LLC, Las Vegas, NV.

Ferguson, J. F., A. H. Cogbill, and R. G. Warren, 1994. “A Geophysical-Geological Transect of the Silent Canyon Caldera Complex, Pahute Mesa, Nevada.” Journal of Geophysical Research, v. 99, no. 33, pp. 4,323-4,339.

Gibbons, A. B., E. N. Hinrichs, W. R. Hansen, and R. W. Lemke, 1963. “Geologic Map of the Rainier Mesa Quadrangle, Nye County, Nevada.” U.S. Geological Survey Map GQ-215, scale 1:24,000. Washington, D.C.

Minor, S.A., 1989. “Paleostress Investigation near Rainier Mesa, Nevada Test Site,” in Olsen, C.W., and Carter, J.A., eds., Fifth Symposium on Containment of Underground Nuclear Explosions--Vol. 2: Mission Research Corp. Report CONF-8909163, p. 457-482.

National Security Technologies, LLC, 2007. A Hydrostratigraphic Framework Model and Alternatives for the Groundwater Flow and Contaminant Transport Model of Corrective Action Unit 99: Rainier Mesa-Shoshone Mountain, Nye County, Nevada.

DOE/NV/25946--146. Prepared for the U.S. Department of Energy, National Nuclear Security Administration Nevada Site Office, Las Vegas, NV

National Security Technologies, LLC, 2008. “Low Water Production from Carbonate Aquifers at Rainier Mesa: Implications for the Distribution of Hydraulic Conductivity within Carbonate Aquifers, Nevada Test Site and Vicinity.” DOE/NV/25946--442. Poster presented at the UGTA Technical Information Exchange Meeting on April 29, 2008. Las Vegas, NV. 
Nevada Bureau of Mines and Geology, 1996. County Digital Geologic Mapping Project- Final Report. Open-File Report 97-1, scale 1:250,000.

NNSA/NSO, see U.S. Department of Energy, National Nuclear Security Administration Nevada Site Office.

Nicol, A., J. Watterson, J. J. Walsh, and C. Childs, 1996. "The Shapes, Major Axis Orientations, and Displacement Patterns of Fault Surfaces.” Journal of Structural Geology, vol. 18, nos. 2/3, pp.235-248.

NSTec, see National Security Technologies, LLC.

Orkild, P. P., 1968. "Geologic Map of the Mine Mountain Quadrangle, Nye County, Nevada.” U.S. Geological Survey, Quadrangle Map GQ-746, scale 1:24,000. Washington, D.C.

Prothro, L. B., S. L. Drellack, Jr., D. N. Haugstad, H. E. Huckins-Gang, and M. J. Townsend, 2009. Observations on Faults and Associated Permeability Structures in Hydrogeologic Units at the Nevada Test Site. DOE/NV/25946--690. Prepared for the U.S. Department of Energy, National Nuclear Security Administration Nevada Site Office by National Security Technologies, LLC, Las Vegas, NV.

Sargent, K. A., and P. P. Orkild, 1973. "Geologic Map of the Wheelbarrow Peak-Rainier Mesa Area, Nye County, Nevada.” U.S. Geological Survey Miscellaneous Geologic Investigations Map 1-754, scale 1:48,000. Washington, D.C.

Sawyer, D. A., R. J. Fleck, M. A. Lanphere, R. G. Warren, D. E. Broxton, and M. R. Hudson, 1994. "Episodic Caldera Volcanism in the Miocene Southwest Nevada Volcanic Field: Revised Stratigraphic Framework, ${ }^{40} \mathrm{Ar} /{ }^{39} \mathrm{Ar}$ Geochronology and Implications for Magmatism and Extension.” Geological Society of America Bulletin, v. 106, pp. 1304-1318.

Scholz, C. H., 2005. The Scaling of Geological Faults. $11^{\text {th }}$ International Conference on Fracture, March 20-25, 2005. Turin, Italy.

Slate, J. L., M. E. Berry, P. D., Rowley, C. J. Fridrich, K. S. Morgan, J. B. Workman, O. D. Young, G. L. Dixon, V. S. Williams, E. H. McKee, D. A. Ponce, T. G. Hildenbrand, WC Swadley, S. C. Lundstrom, E. B. Ekren, R. G. Warren, J. C. Cole, R. J. Fleck, M. A. Lanphere, D. A. Sawyer, S. A. Minor, D. J. Grunwald, R. J. Laczniak, C. M. Menges, J. C. Yount, and A. S. Jayko, 1999. Digital Geologic Map of the Nevada Test Site and Vicinity, Nye, Lincoln, and Clark Counties, Nevada and Inyo County, California. U.S. Geological Survey Open-File Report 99-554-A, scale 1:120,000.

U.S. Department of Energy, National Nuclear Security Administration Nevada Site Office, 2006a. Completion Report for Well ER-12-3, Corrective Action Unit 99: Rainier MesaShoshone Mountain. DOE/NV/11718--1182. Prepared by Bechtel Nevada, Las Vegas, NV.

U.S. Department of Energy, National Nuclear Security Administration Nevada Site Office, 2006b. Completion Report for Well ER-12-4. DOE/NV/11718--1128. Prepared by Bechtel Nevada, Las Vegas, NV. 


\section{$\underline{\text { Copies }}$}

Bill R. Wilborn

Environmental Restoration Project

1 paper/1 CD

U.S. Department of Energy

National Nuclear Security Administration

Nevada Site Office

P.O. Box 98518, M/S 505

Las Vegas, NV 89193-8518

U.S. Department of Energy

1 CD (uncontrolled)

National Nuclear Security Administration

Nevada Site Office

Technical Library

P.O. Box 98518, M/S 505

Las Vegas, NV 89193-8518

U.S. Department of Energy

National Nuclear Security Administration

2 CDs (uncontrolled)

Nevada Site Office

Public Reading Facility

c/o Nuclear Testing Archive

P.O. Box 98521, M/S 400

Las Vegas, NV 89193-8521

U.S. Department of Energy

Office of Scientific and Technical Information

1 electronic (uncontrolled)

P.O. Box 62

Oak Ridge, TN 37831-0061

Navarro-Intera Library

Navarro-Intera, LLC

P.O. Box 98952, M/S NSF167

Las Vegas, NV 89193-8952

Naomi M. Becker

1 paper/1 CD

Los Alamos National Laboratory

P.O. Box 1663, M/S T003

Los Alamos, NV 87545-1663

Bruce M. Crowe

1 paper/1 CD

Navarro-Intera

P.O. Box 98952, M/S NSF167

Las Vegas, NV 89193-8952

1 paper/1 CD

Dist-1 


\section{$\underline{\text { Copies }}$}

Sam J. Marutzky

1 paper/1 CD

Navarro-Intera

P.O. Box 98952, M/S NSF167

Las Vegas, NV 89193-8952

Walter W. McNab

1 paper/1 CD

Lawrence Livermore National Laboratory

P.O. Box 808, M/S L221

Livermore, CA 94551-0808

Charles E. Russell

1 paper/1 CD

Desert Research Institute

755 E. Flamingo Road

Las Vegas, NV 89119-7363

Bonnie K. Thompson

1 paper/1 CD

Water Resources, Nevada District

U.S. Geological Survey

160 N. Stephanie Street

Henderson, NV 89074-8829 